\title{
The Practice and Potential of Agroforestry in the Southeastern United States ${ }^{1}$
}

Sarah W. Workman and Samuel C. Allen ${ }^{2}$

\section{Foreword}

\section{Foreword contributed by Ramachandran $P$.}

K. Nair, Ph.D., Distinguished Professor and Director, Center for Subtropical Agroforestry (CSTAF), School of Forest Resources and Conservation, University of Florida.

Today's farmers and landowners face many challenges as they seek to make their farms and forestlands profitable, productive and environmentally sustainable. A host of problems-farmland conversion, urbanization pressures, reductions in water quality and availability, soil erosion, irregular cash flows, and increased government regulation-make managing the family farm or forest a difficult task.

In today's challenging agricultural setting, new and innovative approaches to farm production are needed. These approaches should address the various problems faced by farmers, landowners and their communities. They should also be practical, profitable, and low in cost.
In response to these needs, significant efforts are underway in the southeastern United States toward realization of the economic, social and environmental benefits of agroforestry. Various research, education and extension activities are taking place in institutions around the region to address how agroforestry can be applied in sustainable land-use designs. In addition, land managers are gradually taking steps to incorporate these innovative and conservation-oriented practices on their farmlands and forested areas.

The purpose of the following instructional document—officially called a white paper-is to help farmers, landowners, extension professionals and policymakers develop solutions to some of the problems they or their clients face, using agroforestry as a land management tool. This will be done by presenting readers with the various opportunities available in agroforestry, based on a review of current and potential practices in the southeastern United States.

The paper begins with an analysis of some of the issues faced by today's rural landowners, including

1. This document is Circular 1446, one of a series through the Center for Subtropical Agroforestry (CSTAF), School of Forest Resources and Conservation, Institute of Food and Agricultural Sciences, University of Florida. First Published: June 2004. For more information, contact CSTAF, PO Box 110831, Gainesville, FL 32611, or http://CSTAF.ifas.ufl.edu. Portions of this material are taken from Workman, Bannister and Nair (2003), Agroforestry Systems 59: 73-83, courtesy of Kluwer Academic Publishers. Please visit the EDIS Web site at http://edis.ifas.ufl.edu.

2. Sarah W. Workman, Visiting Assistant Professor, and Samuel C. Allen, Postdoctoral Researcher, School of Forest Resources and Conservation and Center for Subtropical Agroforestry, Institute of Food and Agricultural Sciences, University of Florida, Gainesville, 32611.

The Institute of Food and Agricultural Sciences (IFAS) is an Equal Employment Opportunity - Affirmative Action Employer authorized to provide research, educational information and other services only to individuals and institutions that function without regard to race, creed, color, religion, age, disability, sex, sexual orientation, marital status, national origin, political opinions or affiliations. For information on obtaining other extension publications, contact your county Cooperative Extension Service office. Florida Cooperative Extension Service / Institute of Food and Agricultural Sciences / University of Florida / Larry R. Arrington, Interim Dean 
agricultural land-use changes, urbanization, agricultural and forestry intensification, water quality and availability, climate change, sustainability, and alternative production systems.

Next, the paper discusses a number of current and emerging agroforestry practices in the Southeast in terms of their research and field applications, including alley cropping, forest farming, riparian forest buffers, silvopasture, windbreaks, and special applications. It then reviews the benefits, constraints and reasons for adoption of agroforestry as reported by Florida landowners and by natural resource professionals in Alabama, Florida and Georgia. Following this is a discussion of current developments, resources and research needs in agroforestry with regard to education and technology transfer, information and decision support systems, farmer's networks, public policy, and economics. Lastly, a listing of helpful resource agencies is provided.

Readers who would like additional information about agroforestry are encouraged to consult with their local county extension, natural resource or forestry professional about the specific crops, trees, animals and markets that are appropriate for their location. They may also refer to the enclosed list of helpful resources, agencies and publications for more information (see Appendices 2-3), or contact CSTAF. Lastly, readers are encouraged to visit the CSTAF Subtropical Tree/Shrub Database, and the Southeastern Agroforestry Decision Support System (SEADSS) - two online decision-making tools available free-of-charge on the CSTAF Web site.

Numerous CSTAF colleagues and collaborators contributed to the preparation of this document. I am particularly grateful to Drs. Sarah Workman and Samuel Allen for preparing the paper. Thanks are also due to Drs. Michael Bannister and Alan Long for their kind help with repeated reviews. Dr. Workman, with the dedicated assistance of Andrea Garcia, completed the surveys, case studies with Kiara Winans, and other field-research presented in the paper. The helpful input of CSTAF partners Drs. Martha Monroe, Jarek Nowak and Edward Ellis is acknowledged, as well as that of UF graduate students John Bellow, Danelle Harrison, Matt
Langholtz, Soumya Mohan and Kristina Stephen. We are also grateful to CSTAF Advisory Council chair Dr. Gregory Ruark (Director, USDA National Agroforestry Center) and Council member Dr. Evan Mercer (USDA Forest Service) for their review of the draft and insightful comments. The editorial assistance of Cindy Love and Joyce Dolbier is also appreciated. Many other individuals including extension agents and landowners took part in the study and effort leading to this report; I wish to thank them all for their support and cooperation. This work was supported by a USDA IFAFS (Initiative for Future Agricultural and Food Systems)/CSREES (Cooperative State Research, Education and Extension Service) grant.

Let me close by saying that, while the discipline of agroforestry holds great potential, we need landowner innovation to push that potential forward in practical ways. We also need the creative and enthusiastic involvement of extension professionals, policymakers and other key decisionmakers to help spread the word about agroforestry. With this team approach in mind, we believe that it is our families, communities and nation that will ultimately benefit from these collective endeavors.

\section{Introduction}

Farm families in the United States face a host of new challenges as we enter the $21^{\text {st }}$ Century. These challenges include changes in agricultural land use, urbanization of rural lands, agricultural and forestry intensification, changes in water quality and availability, climate change, food security, competition from foreign markets, and many other issues. In turn, these trends are impacting how farmers and landowners manage their lands and natural resources. Some of these major issues and resulting land-management impacts are discussed below.

\section{Current Issues}

\section{Changes in Agricultural Land Use}

The Eastern U.S. has undergone major changes in land-cover use over the past 150 years: 
- From the mid-1800s to the 1930s, forests, woodlands and grasslands were dramatically altered through land clearing for timber extraction and agriculture (Ware 2002) (see Figure 1).

- This period also saw widespread cropland abandonment of up to 123.5 million acres (ac) in the region.

- Since the 1940s large changes due to conversion from forest to agriculture or urban settlement and from agriculture back to forests have offset each other, resulting in little net change in forest area, though not in stand age composition.

- Today, crop and pasture lands occupy significant portions of land area in the southeastern U.S., while forests occupy more area than all crop and pasture lands combined (NASS 2001).

- The southern states (Virginia to Texas) have just over $200 \mathrm{mil}$ ac in forestland, an amount that has been relatively stable in the area since the 1970s (Ware \& Greis 2002).

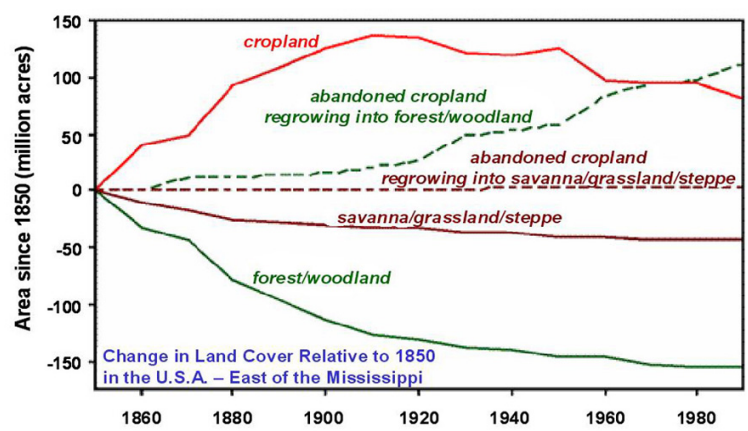

Figure 1. Change in land-cover use east of the Mississippi River since 1850. Note: The data in this figure are from USDA-NRCS-RID 1997. Adapted. Credits: USDA-NRCS-RID 1997. Adapted.

Agriculture and forestry together comprise the single largest sector of the state economy in Alabama and Georgia and the second (only to tourism) in Florida. From 1978 to 1997 the value of all farm products sold in the three states doubled. Cash receipt rankings for major agricultural commodities in each state are as follows:
- Alabama: poultry $38 \%$, timber $22 \%$, livestock $18 \%$;

- Florida: vegetables $21 \%$, timber $20 \%$, fruits $19 \%$, ornamentals $16 \%$;

- Georgia: poultry $51 \%$, field crops $21 \%$, timber $16 \%$, livestock $12 \%$ (NASS 2001).

In the Southeast, forestlands have been exploited since before 1700, and many of these areas, important for wildlife habitat and their influence on hydrologic cycles, are not currently under intensive management (Baker \& Hunter 2002; NRC 1998). Various government agencies manage a total of $11 \%$ of the timberland ( $21 \mathrm{mil} \mathrm{ac}$ ) while the remaining $89 \%$ is privately owned: $22 \%$ by forest industry, $21 \%$ by farmers, $12 \%$ by corporations, and $45 \%$ by other individuals or organizations (Conner \& Hartsell 2002). Across the South, from Texas to Virginia, 92\% of the private forest ownership units are less than 100 ac with an average area of 38 acres. Since 1980 there has been a decrease in forest industry ownership and an increase in private corporate ownership including timber investment management organizations (TIMOs) (Conner \& Hartsell 2002). Of the people who own 10 ac or more of forest land, 56\% do not reside on the parcel (Cordell et al. 1998).

A survey by Israel (1990) found that in north and north-central Florida, one-third of forest landowners considered farming their primary occupation and an additional one-fourth were retired. Most had owned their land for 25 to 30 years. Of these owners, $84 \%$ were male and $16 \%$ were female. Just over $28 \%$ had off-farm jobs and $39 \%$ had spouses that worked off-farm. Over one-half had trees and cattle with the primary emphasis on cattle. Tree planting for timber and other forest resources (e.g., wildlife, firewood) accounted for over $80 \%$ of the new enterprises initiated within the five years previous to the study. Approximately three-fourths of the survey respondents said they earned less than $\$ 10,000$ a year from their land or farm and $28 \%$ said they were losing money from the enterprise (Israel 1990).

In a similar survey of north and north-central Florida counties (Israel \& Ingram 1990), small farm operators were found to be managing one to four agricultural enterprises on an average of 27 acres. 
These enterprises included hay-pasture-rangeland (62\% of respondents), cattle (38\%), timber (36\%), fruit trees (20\%), and vegetables (19\%). Of these farmers, $61 \%$ worked off-farm and $45 \%$ had a spouse who worked off-farm. Among the respondents, the average age was 54 years, $82 \%$ were male, $94 \%$ were white, $5 \%$ were African American, and $0.2 \%$ were of other racial background. Family incomes of over $\$ 40,000$ were reported by $37 \%$ of respondents, but income from farming, by comparison, was low. Approximately $44 \%$ reported earning less than $\$ 5,000$ in annual income from the farm operation (Israel \& Ingram 1990).

\section{Urbanization Pressures on Rural Lands}

The urbanization of rural areas, and the resulting increase in land values at the urban/rural interface, are evidence of the expansion of suburbs and cities across America's rural landscape. Essentially, in urbanization, lands that previously supplied food to urban areas, or which were set aside for forests and natural habitats, are channeled into development for expanding populations (Cordell et al. 1998). This trend has arisen in part as urban dwellers have moved to the country and as rural families have moved out of agriculture, in response to economic factors.

The negative impacts of urbanization in the Southeast are most readily felt on the farm in terms of:

- a reduction in the number and size of farms,

- an increase in the average age of farmers, with fewer young people venturing into farming, and

- a general weakening of resource-based rural economies (Workman et al. 2002a; NASS 2001).

This trend does not usually bode well for small farm families. In many cases, the economic pressures of urbanization may cause them to take their farmlands out of production because of higher tax rates, a lack of available and affordable farm labor, or a desire for more stable and profitable off-farm employment (Granskog et al. 2002).
A variety of economic and social problems may arise from urbanization.

Urbanization tends to disconnect resource production, concentrations of resource demand and consumption, and the impacts of consumption (Lambin et al. 2001; Svedin 1999). In addition, conflicts may arise because of rapid modifications of landscapes, proximity of residents with differing opinions towards these changes and the aesthetics of their surroundings, availability of services, and assessment of markets, taxes and values (ICMA 2002; Hawken 1993). The net effect of these changes, if not handled appropriately, can in many cases diminish the overall cultural vitality and integrity of both urban and rural areas (Ware \& Greis 2002; Duryea \& Vince 2001).

In addition, new urban and suburban settlements can fragment rural landscapes and disrupt the natural cycling of water, nutrients and energy that maintain healthy ecosystems. Not seeing these linkages within the landscape can result in short-sighted use of lakes, streams, wetlands, watersheds, coastal water bodies and other natural resources (Carroll 1995). In the policy arena, decisionmakers are often not aware of, or they overlook, landscape linkages during policy formulation, leading to poor long-term management of the environment.

Ultimately, the complex issues surrounding urbanization influence how natural resources are utilized by all consumers. With an increase in population growth across the southern states of 54\% over the last three decades (Cordell et al. 1998), there is call for adoption of land-management practices that both increase the aesthetic and recreational value of lands while protecting and conserving the natural resource base (Bliss et al. 1997; Teasley et al. 1997).

\section{Agricultural Intensification}

Agricultural intensification for cropland, forest products and livestock production has grown steadily in the U.S. over recent decades. This is due in large part to the wide availability of improved agricultural practices and technologies, an effective research-extension partnership, and an increasing consumer demand for high-quality agricultural products. 
As the rate of land clearing slowed in the mid-1900s and intensification focused more on management of land already under cultivation, food and fiber yields per acre increased with increasing inputs of synthetic fertilizer, pesticides and irrigation. By the 1970s, energy intensive cultivation of maximum acreage in row crops produced surplus yields and higher incomes for farmers. However, greater mechanization and farm inputs increased the number of farm loans during this period, resulting in increased farm debt and eventual wide-scale loss of farms to foreclosures during the 1980s (Fitchen 1991). Today, while some small farm families have recovered, many have opted to quit farming due to high input costs and low profits in the face of tough competition from corporate-run farms and cheap foreign products. These conditions have also kept would-be farmers and investors from venturing into farming.

Concerns have also been raised about the long-term sustainability of monocrop systems because of environmental problems resulting from agrochemical pollution, soil erosion, pest problems, and loss of biological diversity. Questions about how wide-scale manipulation of ecosystems alters the natural structure and function of land and water resources have come to the fore and remain as major research and development concerns (Lappé et al. 1998; Vitousek et al. 1997; Sampson \& Hair 1990; Savory 1988). These concerns have led many producers to adopt more environmentally-friendly production systems in an effort to conserve soil, water and nutrients. Producers have also diversified into specialty-crop production systems, such as those for organic, herbal, culinary and ornamental plants, in response to the rising consumer demand for cleaner, safer agricultural products.

\section{Forestry Intensification}

Forestry in the Southeast has followed a similar progression in production intensity over the past few decades, albeit at a slower pace. Up to the 1940s, forests were cut and left to regenerate naturally, with some managers leaving seed trees for that purpose. With the realization that natural regeneration was inadequate to sustain yields and supply paper mills, silviculture began to include establishment of tree nurseries and replanting of sites after land acquisition. Techniques such as direct seeding were improved over time, and a series of changes in site management philosophy occurred. Use of fertilizer at time of planting also increased, especially when phosphorus deficiencies were noted on flatwood sites, leading to an expansion of production area. Mid-rotation timber fertilization also came into standard practice some 20 years ago. In the 1980s weed control increased with the advent of readily available herbicides, and by the 1990s plantation growers had become proficient at minimizing competition from weeds and woody plants. Cloning, tissue culture and other forms of genetic improvement are anticipated to contribute to intensification of forestry practices in the future.

With increased recreation demand and the call to minimize environmental degradation on public lands, extraction of fiber from natural forests has come increasingly from commercial and investment trust lands, and private non-industrial lands. Since 1989, Florida and Georgia together showed a decline of industry timberland of more than 1.1 mil acres. Much of this timberland is now under ownership of private corporations that will likely continue to manage it for wood products (Conner \& Hartsell 2002). As urbanization increases and more and more people desire recreation in natural settings, there will be a continued need for trees outside, as well as within, forests (Long \& Nair 1999; Leakey 1998).

Urban encroachment on or near forestlands has also brought to the fore the issue of fuel-load management for fire suppression. While public sentiment is in support of forest preservation, an increase in the number of widespread wildfires in recent years has shown the importance of pre-emptive fire management practices on public lands. Appropriate vegetation management at the wildland/urban interface of private lands is also needed in response to the fire threat. Alongside these changes, the critical role of fire in longleaf pine (Pinus palustris) habitat restoration is also gaining in public awareness.

Forestlands are also increasingly being used for the production of nontimber forest products (NTFPs). These products, such as pine needles for 
mulch, crafting materials, edible mushrooms and nuts, herbal plants, and forage, are gaining in acceptance by American consumers. These products will be discussed in more detail later in this paper.

\section{Water Quality and Availability}

The southeastern U.S. is home to a vast number of surface and subsurface water bodies. Florida alone has over 7,800 lakes, 4,000 square miles of estuaries, and 50,000 miles of rivers and streams, including major water bodies such as Lake George, Lake Okeechobee, the Everglades, and the St. Johns and Kissimmee rivers (FDEP 2003). In addition, the Floridian aquifer system, underlying almost all of Florida and portions of Alabama, Georgia and South Carolina, occupies a total area of 100,000 square miles, and supplies over 3 billion gallons of water per day for all uses throughout the region (Johnson \& Bush 2002).

The build-up of nitrate, phosphorus and other agrochemicals in the environment and their effect upon surface and subsurface water quality is of growing public concern (Allen 2003). This issue is particularly important in Florida and surrounding areas, as the karst geography of the region is shaped by vast groundwater reserves that are sensitive to nutrient build-up. Intensive agricultural practices have led to inefficient use of applied fertilizers and to contamination of surface and subsurface drainage water through leaching ( $\mathrm{Ng}$ et al. 2000; Bonilla et al. 1999). In addition, animal waste from dairy and poultry farming operations is a significant source of contamination in Florida's groundwaters (Katz \& Bohlke 2000). Such contaminants can leach into groundwater and pollute drinking water wells, as well as create conditions for eutrophication and related ecological disruptions of rivers, lakes, estuaries and aquifers (Ng et al. 2000; Bonilla et al. 1999; Marshall \& Bennett 1998; Johnson \& Raun 1995). Nutrient pollution is also the most common cause of coastal environmental problems, such as red tide and other algal blooms, fish kills, loss of seagrass beds, and some coral reef die-back, that are especially severe in the Southeast and the Gulf of Mexico (Howarth et al. 1997). These on-going threats point to the need for strategies and technologies for mitigating both the negative environmental symptoms and the root causes of water pollution.
Water availability is another major concern affecting people throughout the region, as demand continues to grow for access to fresh water sources. Dams, diversions between basins, and withdrawal for irrigation affect a vast proportion of our national river flows and have caused extensive fragmentation of natural channels (Jackson et al. 1997). In addition, the intense usage of water in the upland watersheds of the southeastern states has resulted in decreased flows, diminished groundwater recharge, and damage to aquatic life, particularly during drought years (Georgia DNR/EPD 2002). Moreover, the population boom seen in Florida and other states, combined with seasonal influxes of tourists and recent low rainfall rates, have placed additional strains on the region's fresh water supplies.

Changes in water use also affect the region's wetlands. Wetlands and bottomland forests are critical links and buffers between upland and coastal environments in the Southeast—-the Atlantic and Gulf Coastal region (USFS 2002; Abernathy \& Turner 1987). These forests contain the richest diversity of plant and animal species east of the Mississippi River; however, only about $20 \%$ of the original 24 mil ac of bottomland hardwoods or original floodplain forests remain (Ainslie 2002; Conner et al. 2001; Wright 2000; NRC 1998). As in other regions, invasive plants, aquatic weeds, plant diseases and other pests are increasingly extensive problems that threaten the integrity of wetland plant communities (West 2002; Campbell 1997).

Recent efforts by the U.S. Environmental Protection Agency, state environmental protection agencies, universities, and other agencies, have led to some improvements in the region's water bodies. For example, the water quality of certain impacted lakes and streams has been improved, and agriculture-related retention ponds and riparian buffers have been constructed. Moreover, communities are now more conscious about conserving municipal water supplies, and farms and industries are trying to reduce point and non-point source pollution.

In addition, significant attention has focused on phytoremediation - natural environmental clean-up using plants - as a way of controlling pollution from 
agrochemicals and wastes. Constructed wetlands and riparian buffers, for example, are useful technologies for treating nutrient-contaminated waters (Baker 1998). Another treatment option is the use of alley cropping, which involves the planting of crops within rows of trees. The effect of trees in such systems is of interest because trees are able to intercept fertilizer nutrients in soil (Nair 1993) and water, and thus may help clean up the groundwater in and around agricultural fields (Allen 2003; Williams et al. 1997).

Overall, significant strides have been made to improve water quality and quantity conditions in recent years. However, much work remains to be done in this area.

\section{Climate Change and Carbon Sequestration}

There is clear and compelling evidence that global warming is occurring, and numerous studies have suggested a link between this phenomenon and human activities that cause carbon release (Parry 2001). The National Climatic Data Center (NCDC 2002) indicates that seven of the ten warmest years in the $20^{\text {th }}$ century occurred in the $1990 \mathrm{~s}$. The widespread dependence on fossil fuels, carbon emissions from industrial plants, and deforestation all contribute to the problem. The likely wide-ranging impacts of global warming on the Southeast include more conflicts over fresh water and potential threats to the region's vital agriculture, forestry, shipping and tourism industries (Montagnini \& Nair 2004; Twilley et al. 2001; UCS 2001). In this light, developing clean energy sources and reducing dependence on fossil fuels is an essential step in reducing greenhouse-gas emissions and creating new economic opportunities for the region.

Implementing sound practices in land- and water-resource use can reduce ecologically harmful side effects of climate change (Parry 2001; Schimel et al. 2001; UCS 2001). In this light, there is a need for a variety of agricultural practices that can help sequester (store) carbon in intensive farming systems across a large area (NAC 2000a,b; Brandle et al. 1992a). Mixed cropping systems are being considered as one way to fight global warming. Because these systems combine annual and perennial plants, they can contain a large amount of carbon in plant tissue, litter and soil, and can help build soil fertility and reduce fossil-fuel based inputs (Nair \& Nair 2003; Wright et al. 2001). These and other conservation-oriented practices, such as wind-, waterand solar-powered technologies, can help reduce both farm costs and greenhouse-gas emissions when practiced by a large numbers of landowners over a long period of time.

\section{Agricultural Sustainability and Alternative Production Systems}

Greater protection of our environment and adequate food production are major challenges confronting science and society at the turn of the 21 st Century (FAO 2001; Leakey \& Simmons 1997; Matson et al. 1997). The 2002 Farm Bill places emphasis on increasing our nation's food security while maintaining sufficient yields in sustainable production systems. In this context, sustainability at the farm and forest level means:

- protecting and renewing soil fertility and the natural resource base,

- achieving an integration of natural biological cycles and controls,

- optimizing the management and use of on-farm resources,

- reducing the use of nonrenewable resources and purchased production inputs,

- promoting opportunities in family farming, farm communities, and forestry,

- providing adequate and dependable farm and forest income, and

- minimizing negative impacts on health, safety, wildlife, soil and water quality, and the environment (USDA-SARE 2003).

This focus on agricultural sustainability also means adopting alternative production systems. Ideally, sustainable production should manipulate the biological interactions between components and emphasize species diversity rather than simply crop yield (Matson et al. 1997; Scoones \& Thompson 1994). In this regard, a survey of professionals in 
southern states by Zinkhan and Mercer (1997) stated that the most efficient and economical production schemes on marginal crop and pasturelands in the Southeast are probably tree-crop and tree-forage combinations. These are practices that integrate agriculture with livestock and forestry, to produce regular cash flows, improve marginal sites, and enhance wildlife habitat and water quality.

These issues illustrate the need for creative approaches to land use, which meet economic, social and environmental goals in a sustainable manner. Along with these approaches, there needs to be increased recognition that small farms provide tangible goods and services that maintain fundamental ecological processes and social benefits for the nation as a whole.

\section{Agroforestry: A New Way of Thinking about an Old Way of Farming}

In response to these issues, the age-old practice of agroforestry has been reawakened and brought to the forefront of international attention. Agroforestry, the intentional growing of trees with crops, pasture and/or animals, offers promise as an alternative land-use practice with potential for alleviating certain environmental and economic problems associated with modern agriculture (Nair 1993). Practiced in various forms since ancient times in regions such as China, the Mediterranean, and pre-colonial America (Newman \& Gordon 1997; Nair 1994; Linnartz \& Johnson 1984), agroforestry is now gaining interest from researchers, landowners, and government and private agencies in North America.

A key aspect of agroforestry is the wide variety of land-management options it affords for conserving natural resources and producing income (ICRAF 2000; Lassoie \& Buck 2000; Garrett et al. 2000). By integrating trees with crops and/or animals on the same site, agroforestry can provide numerous environmental benefits. These include protection against loss of topsoil and applied nutrients, regeneration of soil fertility, enhancement of water infiltration and groundwater recharge, protection against wind, snow, noise, odor and other nuisances, and creation of attractive and healthier landscapes (Ewel 1999; Jordan 1998b, Daily 1997; Leakey 1996).
Agroforestry practices can also provide a variety of agricultural products and income sources. The multiple products that come from these complementary mixtures are available at different time intervals, can utilize space more effectively, and can utilize nutrients and other farm inputs more efficiently. These diverse combinations can also help buffer landowners from the risk of income loss due to price variability, crop failure or other unanticipated problems. Additional system features can be incorporated to promote recreational, educational and other options on landholdings, thus offering additional sources of income.

Finally, the practice of agroforestry goes hand-in-hand with the idea of land stewardship, because it reaffirms to landowners that they are being good stewards of their lands and are thus providing future generations with healthier ecosystems (Nair 1994). Opportunities for expanding the use of agroforestry practices, and the benefits that result, are gradually increasing in the southern U.S.

Particular agroforestry designs will depend on landowner objectives and can involve any combination of timber, forage, row crop, fruit crop, firewood, livestock, wildlife or recreational habitat. In this paper we explore how agroforestry practices can provide private landowners with methods to better manage landholdings of all sizes across the landscape, to help sustain the family farm and conserve natural resources.

Some of the environmental and economic benefits of agroforestry are presented in Table 1 .

Table 1. Various benefits of agroforestry

\begin{tabular}{|ll|}
\hline \hline Aesthetics & $\begin{array}{l}\text { Promotion of wildlife and plant } \\
\text { diversity and provision of } \\
\text { recreational and leisure } \\
\text { areas. }\end{array}$ \\
\hline $\begin{array}{l}\text { Animal } \\
\text { Production }\end{array}$ & $\begin{array}{l}\text { Improvement of health and } \\
\text { weight and reduction of feed } \\
\text { costs. Shielding of noise and } \\
\text { odor. }\end{array}$ \\
& \\
& \\
\hline \hline [continued]
\end{tabular}


Table 1. Various benefits of agroforestry

\begin{tabular}{|ll|}
\hline \hline $\begin{array}{l}\text { [continued from } \\
\text { previous page] } \\
\text { Carbon Storage }\end{array}$ & $\begin{array}{l}\text { Incorporation of large quantities } \\
\text { of carbon in woody vegetation } \\
\text { within the agricultural } \\
\text { landscape. }\end{array}$ \\
\hline Economic & $\begin{array}{l}\text { Promotion of income from } \\
\text { multiple products with steady } \\
\text { cash flow. Reduction of input } \\
\text { costs and improvement in } \\
\text { quality and yield of crops. }\end{array}$ \\
\hline Energy & $\begin{array}{l}\text { Reduction of farm and } \\
\text { household energy costs and } \\
\text { inputs. }\end{array}$ \\
\hline Pest Management & $\begin{array}{l}\text { Provision of barriers to } \\
\text { reproduction and spread of } \\
\text { pests, and habitat for beneficial } \\
\text { insects and birds. }\end{array}$ \\
\hline Soil Conservation & $\begin{array}{l}\text { Reduction of loss of nutrients, } \\
\text { organic matter and sediment } \\
\text { erosion. }\end{array}$ \\
\hline $\begin{array}{l}\text { Interception of agricultural } \\
\text { runoff and sediment, protection } \\
\text { of banks from erosion and } \\
\text { safeguarding of habitat. }\end{array}$ \\
\hline Wetlands
\end{tabular}

\section{Emerging Agroforestry Practices in the Southeast}

Agroforestry can be divided into six major practices or land-use techniques (Sinclair 1999; Merwin 1997; Garrett et al. 1994):

- Alley Cropping

- Forest Farming
- Riparian Forest Buffers

- Silvopasture

- Windbreaks

- Special Applications

This section will describe each of these practices in detail, and how researchers and landowners are applying them in the Southeast. For a brief overview of these practices, see Workman et al (2002b). See also Appendix 2 for a list of agroforestry resources on the Web, and Appendix 3 for a list of agroforestry incentive programs for Alabama, Florida and Georgia.

\section{Alley Cropping}

Alley cropping consists of planting herbaceous or other crops between widely spaced rows of trees or shrubs. The wide alleys are easily farmed with standard equipment. Cash crops grown in the alley could be hay, corn (Zea mays), cotton (Gossypium spp.), watermelon (Citrullus lanatus var. lanatus), squash (Cucurbita spp.), other vegetables, berries, or Christmas trees. In addition, the growing demand for medicinal or specialty crops, such as ginseng (Panax spp.), ethnic vegetables, herbs, and bamboo, may provide additional candidate crops for alley production (Diver 2001; Garrett \& McGraw 2000). While the tree crop matures, the alley crops provide annual income (Benjamin et al. 2000; Cutter et al. 1999; Jordan 1998b; Lewis et al. 1985). Depending on the level of shade provided by the tree row over time, the alley crop could be changed to match the changing conditions.

Trees can be planted in single or multiple tree rows and thinned for pulpwood, firewood or fencing while they are small in diameter. Larger trees may be harvested for lumber or other high-value products. Preferred tree species are pines (Pinus spp.) and hardwoods such as pecan (Carya illinoensis), ash (Fraxinum spp.), oak (Quercus spp.), persimmon (Diospyros virginiana), cherry (Prunus spp.), and poplar (Populus spp.). Nuts and fruits produced by pecan, persimmon and walnut (Juglans nigra) can provide an intermediate income, often coming into full production about the time alley crop production is shaded out (Figure 2). 


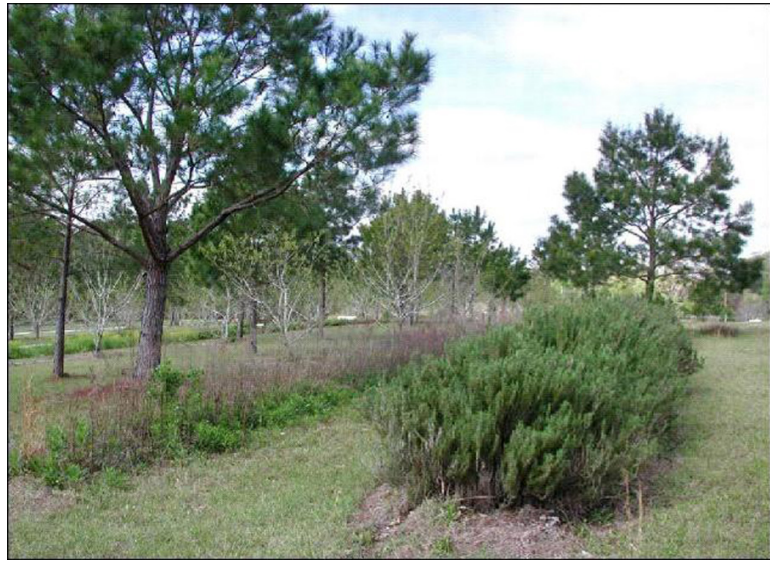

Figure 2. Persimmons, ornamentals and rosemary intercropped with pines in northern Florida. Credits: CSTAF.

In addition, fruiting or ornamental shrubs such as blueberry (Vaccinium spp.) or huckleberry (Gaylussacia spp.) can be established instead of trees, or grown in the alleys instead of crops for fruit or floral industry products (e.g., decorative boughs). Ground cover and fruit-bearing shrubs next to trees can also provide wildlife travel lanes, food, and cover. This practice improves financial returns by more intensive and diversified use of space with combinations of annual and perennial crops; however, it may decrease the production of any single component in the system.

Alley cropping with nut- or fruit-bearing trees is one of the more common practices. Systems with black walnut are well developed in the Midwest (Gillespie et al. 2000; Jose et al. 2000a,b; Garrett \& Kurtz 1983), as are other hardwood-based systems farther north (Garrett \& McGraw 2000; Williams et al. 1997). Southern pecan orchards are sometimes intercropped with cover crops or forage for hay/grazing, but in some cases are cropped with grain or vegetable crops for the first few years until pecans come into full production (Reid 1991; Bugg et al. 1991). In these systems, pecans may be planted in a $40 \times 40 \mathrm{ft}$ grid spacing initially and then be thinned at 16-20 years and again at 25-35 years. Peach (Prunus persica $\mathrm{L}$.) trees are another option for intercropping with pecan, as they can often bear fruit and be removed prior to nut production.

Some citrus growers practice alley cropping by cultivating horticultural crops between young citrus seedlings for the first few years after orchard establishment. Similarly, some farmers producing for farmers markets or community-supported agriculture groups (CSAs) have adopted innovative designs combining fruit and nut trees or fruiting shrubs with horticultural or ornamental crops. Interestingly, such combinations of diverse cover crops and trees may support insects beneficial in biological control of pest species, such as in pecan (Bugg et al. 1991).

Alley hedgerows can be useful in controlling erosion and increasing water infiltration, especially on sloping lands (Jordan 1998a). Trees on contours also encourage formation of natural terraces as a result of tillage, especially when combined with practices that reduce surface soil and debris movement. This would be particularly useful on highly erodible soils and in areas taken out of production for conservation.

Alley tree harvest rotations can also be used to advantage to interplant Christmas trees or short rotation woody crops (SRWC) between timber species (Merwin 1997; Kurtz et al. 1991). A SRWC of fast-growing tree species at close spacing harvested on a short rotation of 6-10 years for energy or fiber products (Rockwood 1996; Rockwood et al. 1993; Colletti et al. 1991) can be combined with forage or row crops in alley cropping systems. Such systems may be used to treat wastewater, municipal sludge, and livestock waste effluent (Rockwood 1997; Schultz et al. 1995; Colletti et al. 1994). Of interest in this regard, Malik et al. (2000) tested a mixture of annual and perennial grass and legume species for erosion control in SRWC stands. They found a ryegrass (Lolium multiflorum) and crimson clover (Trifolium incarnatum) mixture to be most effective for erosion control in the early years of stand development.

A current agroforestry research project in Alabama incorporates alley cropping for soil and water conservation using mimosa (Albizia julibrissin), blackberry (Rubus ursinus), and switchgrass (Panicum virgatum) as hedgerow species (Shannon et al. 2002). This agroforestry practice is being tested as an alternative to conventional pipe-outlet terraces. A previous alley cropping trial was established at Alabama A\&M Agricultural Research Station north of Huntsville in 1998 using 
several timber species with winter wheat (Triticum aestivum L.) and soybeans (Glycine max) intercropped the first year (Cannon 1998). Intercropping has continued with the soybean rotation, and other crops are also being tried between paulownia (Paulownia fortunei), pecan, cherrybark oak (Quercus pagoda), and yellow poplar (Liriodendron tulipifera). Paulownia has shown the greatest response to fertilization (Gray 2001). Cannon (1998) suggested that the search for timber trees for alley cropping can be combined with the search for species for windbreaks/line plantings and pasture dividers since more intensive management (i.e. pruning) could increase the value of resulting products in either practice. These thoughts were echoed in the collection on silviculture for agroforestry systems by Ashton and Montagnini (1999).

A research team in northwest Florida has examined tree-crop interactions in alley cropping systems of loblolly pine (Pinus taeda), longleaf pine, or pecan associated with cotton, crimson clover, ryegrass, and bahiagrass (Paspalum notatum). They are quantifying above- and below-ground interactions between trees and cotton, and cotton yield in relation to tree rows. Triple rows of young pine trees are planted to create two different alley widths to accommodate 8 or 16 rows of crops. In addition, a cotton intercrop study was established in a mature pecan orchard with an alley spacing of 60 feet (Allen 2003). Scientists are currently analyzing results from the Florida trials to determine spatial variation in crop yield, soil water, nutrient competition, and various physiological responses of the plant components (Allen 2003; Lee \& Jose 2001). Analysis of cultural practices and pesticide management in the established systems indicates that growers harvesting from a multi-crop design may encounter problems with pesticide labeling and use restrictions (Ramsey \& Jose 2002). The study also points out the need to develop alternative cultural and integrated pest management practices. Selecting pest resistant varieties and cultivars, mechanical weed control, trap plants and foliar sprays, are viable alternatives in multi-crop systems (Ramsey \& Jose 2002).

Extensive agroforestry research has also been carried out by the University of Georgia. In green manure trials using row crops between mimosa (Albizia julibrissin) hedgerows, mimosa was more effective at tapping unavailable forms of phosphorus than a winter crop of crimson clover. Leaf litter of mimosa significantly increased soil nitrate and ammonium forms of nitrogen compared to conventional green manure (Rhoades et al. 1998; Matta-Machado \& Jordan 1995). The rapid rate of leaf decomposition, that makes it attractive as a green manure, could be complemented through addition of another component as a more lasting mulch cover for alleys (Jordan 1998a).

In the U.S. Virgin Islands, tree-crop integration takes the form of hedgerow intercropping. The noni tree, Morinda citrifolia, has been planted with hot peppers in the alleys, and other medicinal trees are intercropped with high-value herbs and spice crops. The research is designed to evaluate the influence of trees on resource use, soil fertility and yield of intercropped specialty crops, tree influence on pest populations and chemical pesticide inputs, and the economic benefits of these intercropping designs (Palada 2002). A follow-up study investigating the response of Morinda to pruning to improve its growth form showed that early pruning tended to reduce tree development.

The Association for Temperate Agroforestry (AFTA 2000) recently delineated strategic questions and needs for the major agroforestry practices that are equally applicable in subtropical areas. Research questions that need to be addressed for alley cropping focus on compatible crop rotations with tree-shrub species, yields in different combinations, optimal row spacing, weed control at crop-tree row interfaces, and integrated pest management components. Technology transfer needs include region-specific ratings for species combinations, management guidelines, marketing information, financial analysis models, and plant materials information.

\section{Forest Farming and Nontimber Forest Products (NTFPs)}

This practice utilizes forested areas for producing specialty crops that are sold for ornamental, culinary or medicinal uses. Specialty crops that tolerate partial shade include herbs, wildflowers, saw palmetto (Serenoa repens), ferns, 
mushrooms such as morels (Morchella spp.) and shiitake (Lentinula edodes), and fruits such as plums (Prunus spp.), pawpaw (Asimina triloba), mayhaw (Crataegus opaca), and wild berries. Other nontimber products that can be collected and marketed from shaded conditions are honey, pine straw for mulch, and crafting materials. While many of these products have traditionally been collected from natural sources, in forest farming, intentional management of the crop plants and the overstory trees can increase specialty crop productivity (Figure 3 ). The overstory trees can also be harvested for timber products, either during regular forest farming operations or in a final harvest. Specialty products produced in forest farm designs can supplement family income and increase product diversity on the site.

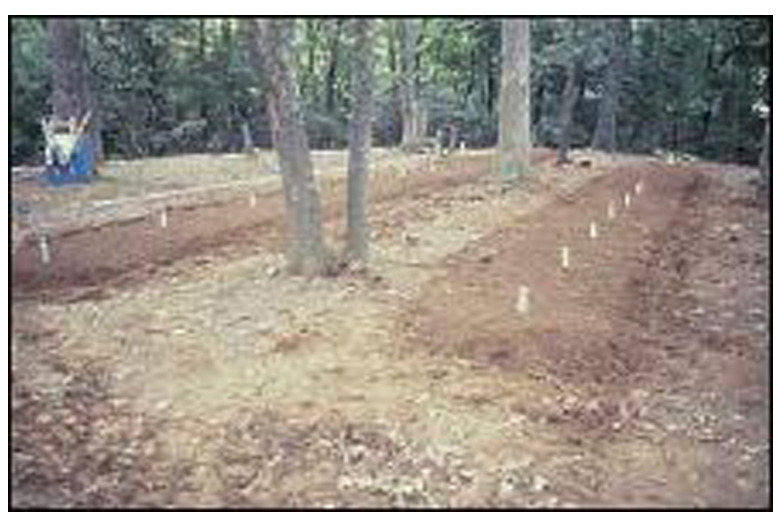

Figure 3. Forest farming. Credits: NAC. Used with permission.

The intentional cultivation of diverse products on forested land is practiced successfully all over the world. The multi-storied nature of these systems allows for cultivation of specialty crops at various layers-as belowground root crops, as herbaceous ground covers, as shrubs, as understory trees, and as trees in the canopy. Forest farming is especially useful for commercial production of shade-tolerant specialty crops, species being over-exploited in natural forest settings, and where long-term collecting and sustainability are of concern. In addition, forest farming for specific products can be promoted as part of timber stand improvement, standard silvicultural activities to improve forest value, and management of public lands (Hill \& Buck 2000).

Reviews of forest farming practices in North America (Hill \& Buck 2000; Dix et al. 1997;
Williams et al. 1997; Thomas \& Schumann 1993; Smith 1953) and texts on forest gardens (Hart 1991) and homegardens (Nair 1993; Soemarwoto 1987) explain many of the principles of the cultivation systems along with providing examples of which forms these systems take. There are also excellent treatments of nontimber forest products (Jones et al. 2002), forest medicinals (Duke 1997; Davis 1993; Foster 1993; Miller 1988) and their markets in specific regions including the Pacific Northwest (Schlosser \& Blatner 1997; Hagen et al. 1996), the Mid-Atlantic (Chamberlain \& Hammett 1998; Hill \& Webster 1996), the Midwest (Gold \& Godsey 2002; Josiah 1999, 2001b; Baughman 1996; Mater 1994), the Rocky Mountains and Southwest (Belonogova 1993; Hernandez \& Abud 1987) and the Northeast (Teal \& Buck 2002; Buck 1999). Jones et al. (2002) include a brief but commendable description of Florida and the Caribbean area (Weigand 2002) that highlights indigenous cultural uses and the potential for development of medicinal plant cultivation in the U.S. subtropics.

Chamberlain and Hammett (2002) have identified four major categories of nontimber forest products: edible and culinary products, medicinal and dietary supplements, floral and decorative products, and specialty wood products. Blueberries, huckleberries, honey and mushrooms are examples of the most common edible and culinary products. Witch hazel (Hamamelis spp.), digitalis (Digitalis spp.), camphor (Cinnamomum camphora), saw palmetto and ginseng are all well-known medicinal plants from forested areas. Decorative and floral products include greenery, Spanish moss, dried plants, berries and flowers, wreath materials, and aromatic oils. Products produced from parts of trees, saplings or woody vines, such as furniture, musical instruments, and utensils, are considered specialty wood products.

Apiculture and forest management combine well in forest farming. A number of forest species such as blackgum (Nyssa sylvatica), persimmon, tulip poplar (Liriodendron tulipifera) and gallberry (Ilex glabra), for example, produce nectar and pollen attractive to bees who in turn serve as pollinators and help assure tree seed production for forest regeneration (Alexander \& Alexander 2002; Hill \& Buck 2000). In 
addition to honey, a number of products can be developed from beehives, and moving bees and hives on short-term contract as pollinators can be a lucrative business.

Mushroom production is another forest farming activity that has proven to add value to under-utilized wood products and diversify income streams for producers. Native mushrooms, such as chanterelles (Cantharellus spp.) and morels, have long been harvested as edibles, while exotics, such as shiitake and various oyster mushrooms (Pleurotus spp.) are increasingly cultivated for popular markets. Thinning operations in forests that yield small diameter hardwood logs provide the ideal substrate for small scale production of shiitake and other gourmet mushrooms. Small forest patches can also be cleared for mushrooms, such as morels, that prefer forest floor litter as a growth substrate (Hill \& Buck 2000; Hill 1999).

Production and marketing of mushrooms has been studied in the Southeast, e.g., shiitake on oak logs under pines in western Alabama (NARC\&DC 2000). In addition, cooperative efforts between statewide producers' associations in Alabama and Florida have been developed with partners in Soil and Water Conservation Districts and university extension (Alabama A\&M University, Auburn, and University of Florida). In this instance, developing a market for the product was a challenge. Producers who retained steady markets and flexibility with seasonal production and labor demands were able to continue production and in some cases developed year-round enterprises (NARC\&DC 2000; Stamets 2000; Sabota 1993; Rathke \& Baughmann 1993). Farmer-to-chef markets have been promoted for herbs, mushrooms and specialty vegetables grown in managed forest settings. In south Florida, producers are using melaleuca as a growth substrate for the medicinal Rishi mushroom (Ganoderma sp.) and are cultivating oyster and other edible mushrooms on sawmill waste.

Markets for herbal supplements have grown significantly over the past ten years. In fact, plant-derived medicines and herbs from forest settings are likely the highest valued trade items (Chamberlain \& Hammett 1998, 2002) though formal tracking of marketing is difficult (Alexander et al. 2002). Witch hazel, digitalis, camphor, saw palmetto and ginseng are all well-known medicinal plants from forested areas. Additional forest plants in the Southeast that are used as medicinals include bloodroot (Sanquinaria canadensis), mayapple (Podophyllum peltatum L.), and yellow jasmine (Gelsemium sempervirens). Several medicinal plants that are used in Ayurvedic and homeopathic medicine are native to the West Indies and subtropical America. These species include pond apple (Annona glabra), herb-of-grace (Bacopa monnier), false daisy (Eclipta alba), and llima (Sida cordifolia), among others (Weigand 2002; Demurs 1997; Morton 1981). Markets fluctuate, however, and it is important to understand projected demand and identify buyers for these specialty products (Chamberlain \& Hammett 2002; Alexander et al. 2002).

The most widely recognized forest farming activity in the Southeast is gathering pine straw, which has increased in popularity since the 1980s (Brauer \& Burner 2001; Duryea 1988; McLeod et al. 1987). Under optimal conditions with fertilization management (Morris et al. 1992), this NTFP alternative combined with hunting or other fee uses could add about $20 \%$ more income for landowners with mid-rotation longleaf pine stands (Bean 2002). Longleaf and slash pines are preferred for straw because they have longer needles that bale most easily for landscaping mulch and they retain a red or brown color longer than other pines. Though needles can be raked annually, most managers recommend raking only four to five times after year eight during the tree rotation. Maximum needle yield at age 15 is estimated to be 200 to 300 bales per acre (Duryea 2000). Baled pine straw delivered to the seller may earn \$750-1000 per acre per year (wide sale range per bale, $\$ 0.50$ or greater) or $\$ 75-150$ per acre gathered by a supplier. Once stands are thinned they are seldom used for pinestraw, but they may generate an additional $\$ 15$ per acre (or more with incorporation of wildlife food plots) from a hunting lease versus $\$ 2$ per acre in unmanaged forestland (Bean 2002).

Other examples of forest farming include cultivating ferns, palmettos for fronds, or other ornamentals under shade (e.g., oak forest). Greenery products gathered from forests are sold for floral and holiday markets. Tips from lower limbs of conifer 
trees serve as raw materials for loose greenery, garlands, centerpieces, and wreaths or swags (Hammett \& Chamberlain 2002). Numerous broadleaf evergreens and other herbaceous ornamentals exist in the coastal plain vegetation. Early in the 20th century for example, a fern grower's association developed out of Apopka, Florida, to supply asparagus-fern (Asparagus setaceus) to stores in the northeastern U.S. This foliage industry grew as a contract grower-brokerage business and evolved with changing modes of transportation and markets promoting leatherleaf (Rumohra adiantiformis) and asparagus-fern. In 1997 the industry grew floral greens on over 7,300 ac of land in Florida, with sales totaling \$85.5 million (FFGA 2001). These fern growers continue today as profitable enterprises with an expanded offering of floral greens, grown under shade of native or managed oak forest.

The history of crafting items from forest-collected materials (wildcrafting), the foliage industry, and the use of medicinals, especially within specific cultural groups, provides an open door for development of forest farming practices in the region (Teal \& Buck 2002). However, assessing which understory cropping practices are compatible with timber stand improvement/management and which cultivars are available for use, are questions that need to be addressed (AFTA 2000). We need to compile information on which shade-tolerant species and NTFPs in the region have economic potential, document their growth and management requirements, and determine market strategies with producers. It is also possible NTFPs can be managed on native range (Tanner et al. 1999; Bennett \& Hicklin 1998) or integrated into fence lines and riparian forest buffers. The potential for development of NTFP enterprises holds promise not only for the Southeast but also in the Caribbean.

Strategic research questions outlined for forest farming (AFTA 2000) focus on which tree densities and regulated shade levels provide appropriate microclimate and growing conditions for specialty crops, growth requirements for valued NTFPs, start-up/operating costs, compatible forest management strategies, influence of shade levels and genotypes on chemical activity and production gains, evolving markets, and how forest farming compares with other forest land uses. There is also a need to assess the relationships between forest management practices, nontimber forest products, and biodiversity of forest populations (IFCAE 2003).

Technology transfer needs identified for forest farming practices include: wholesale and retail marketing information at region-specific levels; production guidelines that outline species/cultivar information, plant material sources, and compatible forest management regimes; and financial analysis models and enterprise budgets for practices and common specialty crops (AFTA 2000). Promise of buyer, and possibly harvester, involvement in inventorying and monitoring specialty forest products holds effective potential impact for NTFP longevity (IFCAE 2003).

\section{Riparian Forest Buffers}

This practice is already common in the Southeast since forest landowners maintain vegetation buffer strips along streams according to Forestry Best Management Practices (BMPs) in each state. Basically, riparian forest buffers are strips of trees and annual vegetation along stream channels or aquatic shorelines. Generally speaking, these areas are adjacent to water bodies, have no clear boundary delimitations, serve as transitions between aquatic and upland settings, and are linear in shape and appearance (Schultz et al. 2000). Riparian forest buffers, whether natural or created, have a dominant woody component, unlike vegetative filter strips that are used to intercept surface runoff in agricultural settings. Buffers vary in design according to the intended management objectives (Lowrance et al. 2001; Schultz et al. 2000) including tree crop management (Dosskey et al. 1997a,b; Sykes et al. 1994).

Riparian buffers provide numerous environmental benefits. In general, they play an important role in the hydrologic cycle between surface and ground water, and the movement of non-point source pollution into water bodies (Lowrance et al. 1997; Verchot et al. 1997; Welsch 1991; Lowrance et al. 1985). Specifically, they provide vegetative resistance that serves to trap sediment, slow flood flows, and provide waterbreaks in floodplain areas (Wallace et al. 2000; Daniels \& 
Gilliam 1996). They filter and process runoff, storm water, and drainage from lawns, roads and other urban sites. They also help hold water and control stream bank and in-channel erosion to help stabilize water corridors (Qiu \& Prato 1998; Dosskey et al. 1997a,b; Correll 1983).

Riparian buffers also have the capacity to sequester large amounts of carbon through active tree growth (Pallardy et al. 2002; NAC 2000a,b) and play a critical role in maintenance of regional biodiversity (Naiman et al. 1993). In addition, they provide wildlife and aquatic habitat, influence shade, modify winds, screen out noise, and provide aesthetic benefits (Schultz et al. 2000). Riparian zones can thus be managed for environmental services as well as a variety of products, including fruit, nut, and ornamental combinations (Robles-Diaz \& Kangas 1999).

The width of the riparian forest buffer depends on BMP guidelines, the condition of the waterway/wetland, and site characteristics such as slope and the type of soil. Landowner objectives may even call for buffer strips wider than BMP guidelines. In agricultural settings, buffer strips can be managed intensively or can be restored by planting strips of perennial vegetation between fields and water. Strips may often be planted in multi-layer patterns where unprotected waterways cross agricultural land (Workman et al. 2002b) (Figure 4). Bioengineering techniques are available for streambank stabilization and restoration in degraded areas (Wells 2002).

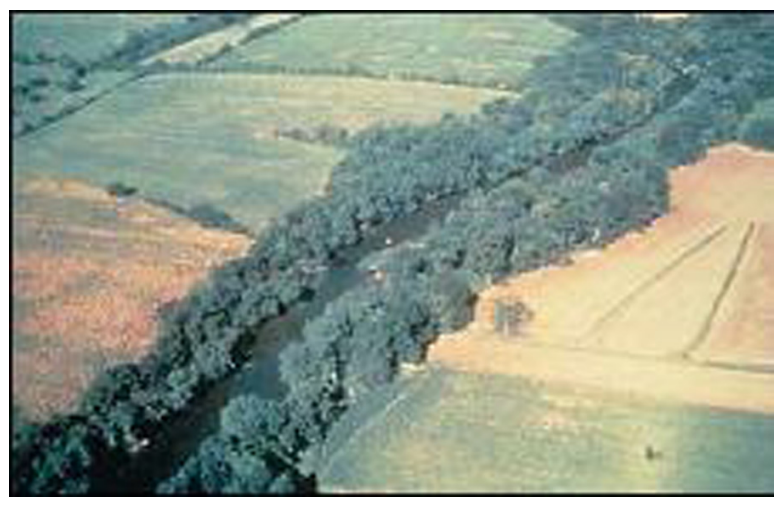

Figure 4. Riparian forest buffer. Credits: NAC. Used with permission.

The trees, shrubs and grasses that are suggested for use in riparian buffer strips and streamside management zones need to be tolerant of occasional flooding or wet soil conditions. Those with a well-developed, shallow root system will be more efficient in uptake of nutrients and agrochemicals. Tree species used in these buffers range from cypress (Taxodium spp.) and tupelo (Nyssa spp.) to willows (Salix spp.), maples, poplars, ash and oaks. Shrubs can include wax myrtle (Myrica cerifera), buttonbush (Cephalanthus occidentalis), viburnum (Virburnum spp.), gallberry or other hollies (Ilex spp.). While switchgrass (Panicum virgatum) is often used for a grass buffer strip, any number of native species can also be used in the grass/herb component.

Research questions that need attention for riparian forest buffer practices include: carbon storage and movement dynamics above- and below-ground; design criteria of age, width and vegetation type; management influences on buffer capacity to process sediments, nutrients and agrochemicals; site characteristics and hydrology influences on buffering capacity and flood protection; variability of buffer effectiveness in different seasons and contaminant loadings; and inclusion of species valued for wildlife habitat or income-generating products (AFTA 2000).

\section{Silvopasture Practices}

Silvopasture intentionally combines trees with livestock and forage production. The Southeast leads the nation in development of this practice because good growing conditions can be maintained for both timber and livestock production on the same site. Benefits to the farmer include income generation while converting from crop to timber (or vice versa), improvement in water quality, wildlife habitat, and soil erosion control. In the Southeast, these systems vary from rotational grazing in pine forests or plantations, to intentional grazing under hardwoods and pecan orchards.

For silvopasture, trees are planted or thinned to provide sufficient light for good forage production. High value timber species can be intensively managed in widely spaced rows, and are most often grouped in double or triple rows to improve form (e.g., double-rows $8 \mathrm{ft}$ apart, $4 \mathrm{ft}$ between trees within a row, and $40 \mathrm{ft}$ to next set of trees). Some landowners have adopted these systems using bahiagrass as a summer forage and clover, ryegrass or 
rye as a winter forage. Some orchards and woodlots incorporate rotational grazing with cattle, goats, sheep or other livestock.

Providing management of the three components of livestock, forage and trees, silvopasture has historically occurred as shade trees in pasture, as grazed orchards or woodlands, and as rangelands that include a managed tree or shrub component (Clason \& Sharrow 2000; Robinson \& Clason 1997; Williams et al. 1997) (Figure 5). Silvopasture in the Southeast has traditionally included forest grazing with cattle, such as flatwoods rangeland (Pearson 1997), pine managed for turpentine and sawlogs with forage (Byrd et al. 1984; Cary 1928), and tree pasture practices with pecan (Reid 1991). Combinations with goats are of interest for meat production and vegetation management (Burton \& Scarfe 1991). The biological limitations and management of each component, and the desired interactions, must be considered during design and species selection (Robinson et al. 2001; Clason \& Sharrow 2000; Clason 1999).

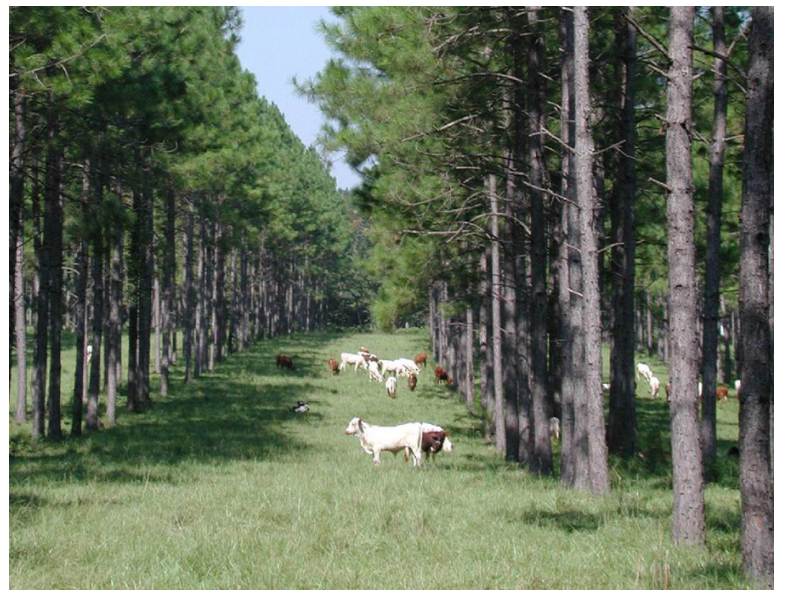

Figure 5. Silvopastoral system with cattle grazing bahiagrass in a slash pine stand. Credits: CSTAF.

Other benefits of silvopasture include increased tree growth, forage production, shade for animals, diversified recreation options, and other products such as pine straw. The long-term benefits of timber production may attract landowners if it combines easily with their annual livestock and haying operations and provides annual income from wildlife and recreation enterprises. The initial tree density or designed thinning can be managed to control canopy cover of less than $30 \%$ for good forage production.
Site disturbance after clearcutting and before replanting can provide an opportunity for planting of forage grasses and legumes.

Lewis and other researchers (Hart et al. 1970) demonstrated that combining the production of southern pines and beef on improved pastures offers an opportunity for multiple product yields. Integrating forestry with ranching may increase profitability and help buffer year-to-year variability in income through the sale of forest products and increased opportunities for sale of hunting leases brought about by the creation of wildlife habitat. Scientists (Lewis et al. 1983; Halls et al. 1957) initiated warm season forage studies under pines in south Georgia in the 1940s that in time showed Pensacola bahiagrass to be the most shade tolerant of the 23 grasses studied (Lewis \& Pearson 1987; Pearson 1975). Several legume species have shown potential for production under partial shade (McGraw et al. 2001). In the Georgia trials, annual lespedeza (Kummerowia spp.) and white clover (Trifolium repens) were promising forage species for silvopasture. Double rows of pines at $8 \mathrm{ft}$ between rows and $4 \mathrm{ft}$ between trees and $40 \mathrm{ft}$ wide alleys produced more forage and as much wood as the single $8 \mathrm{ft} \times 12 \mathrm{ft}$ rows (Lewis et al. 1985), and this remains the most popular spacing for silvopasture across the region today (Clason \& Sharrow 2000). Newer varieties of bahiagrass (Tifton-9 and Argentine), with additional research, may show themselves to be even better warm season forage in silvopasture (Nowak \& Blount 2002).

Studies from across the southern pine region (e.g., Louisiana, Mississippi, and Georgia), report the possibility of productive livestock grazing while maintaining, or even improving, high value timber production. Silvopastoral practice in Louisiana has shown an internal rate of return that was higher $(13 \%)$ than managed timber $(9 \%)$ or open pasture (6\%) (Clason 1995). In southern Mississippi, land expectation values of silvopasture combinations of steers/cows compared favorably with pasture and were higher than timber production. Under varied cost and revenue regimes, including fee hunting, silvopasture and pasture both had positive cash flows with pasture overall highest under the short time period evaluated (Grado et al. 2001). 
In Georgia, there are examples of enhanced pine growth with controlled grazing (Lewis et al. 1985), and models show loblolly-cattle-forage practices on the Coastal Plain may have a 70\% greater net present value than a pure forestry operation per unit area (Dangerfield \& Harwell 1990). Silvopasture trials using simultaneous timber with forage or livestock production are underway in Alabama (Brantley 1998). Researchers have found mimosa and leucaena (Leucaena leucocephala) grown without fertilizers can be cut for fodder at 6-8-week intervals in Alabama (Bransby et al. 1996), while leucaena has been grown in mass and used for feed pellets in Texas (Felker et al. 1998). Another viable combination could be livestock-forage-Christmas tree production, as Pearson et al. (1990) suggested.

There is also increasing interest in goat production in the region (McGowan et al. 1999). Goats have been used by the forest industry in the South as an alternative to using chemical or mechanical weed control in pine plantations (Solaiman \& Hill 1991) because vegetation management is a major factor in water and nutrient competition (Nambiar et al. 1993). The goats can be an effective practice for reducing competing vegetation and can also provide rural forest-based operations with enhanced economic options through goat meat production. Evidence from studies in Arkansas and Alabama indicate that goats can help reduce vegetation, especially kudzu (Pueraria lobata (Willd.)), during site preparation for pine plantations (Pearson \& Martin 1991; Bonsi et al. 1991). On-going investigations to support development of efficient goat production and management systems by Florida A\&M University (FAMU) under their statewide Goat Program include feeding and nutrition components (McGowan et al. 1999).

\section{Windbreaks and Linear or Border Plantings}

Most common in the Midwest and Great Plains, windbreaks are rows of trees around homesteads, farms, and fields that are managed as part of crop or livestock operations. They protect soils, animals, and crops; help reduce dust, odor, and noise; and provide cover and food for wildlife. Windbreaks help prevent frost damage and have increased crop yields as much as 20 percent in some areas. In the Southeast they are important sources of shade for livestock during hot summer months. Even a single row of pine trees around a pasture border will furnish this protection. More typically, windbreaks are planted as multiple rows of mixed species.

Windbreaks are also planted to protect buildings, work areas, roads and community spaces (Figure 6). Virtually any tree or shrub species can be used to establish windbreaks, although each should be evaluated for the planting site and project objective. Evergreens such as pines and eastern redcedar (Juniperus virginiana L.) are ideal for year-round protection. Other effective windbreak species are cottonwood (Populus spp.), boxelder (Acer negundo), and shrubs such as hollies, crabapple (Malus spp.), hawthorns (Crataegus spp.), laurelcherry (Prunus spp.), and flowering ornamentals.

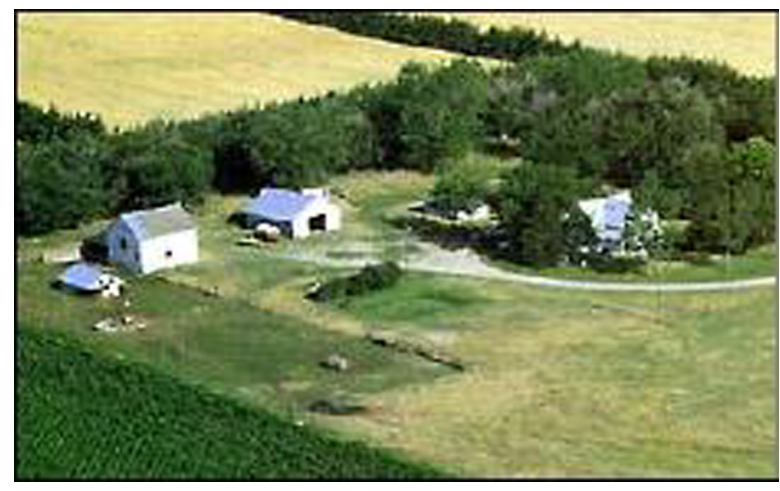

Figure 6. Windbreaks along the borders of a farmlot. Credits: NAC. Used with permission.

Windbreaks provide numerous other benefits. Windbreaks are recognized as a way to reduce wind erosion and soil loss, protect fruit and vegetable crops sensitive to wind (Brandle et al. 2000; Norton 1988), and enhance pastures, most notably in dry climates (Bird 1998; Kort 1988), as well as yield both nontimber and wood products (Josiah 2001c; Cannon 1998; Brandle et al. 1994; Bagley 1988). Increased yields from sheltered crop fields afford positive economic returns to producers with minimal area (5-6\%) taken out of production (Brandle et al. 2000; Brandle et al. 1992b). The presence of windbreaks and hedgerows influences the distribution of crop pests, their predators, and beneficial insects in agroforestry settings (Brandle et al. 2000; Dix et al. 1999; Burel 1996). Protection for livestock and 
confinement areas with windbreaks is especially effective for young animals and for maintenance of body temperature under cold/heat stress (Dronen 1988; Primault 1979). Many of these benefits, such as enhancement of wildlife habitat and control of crop pests (Stamps et al. 2002; Forman 1995; Dix 1991) produce additional economic returns from potential hunting and integrated pest management strategies (Dix 1996; Altieri 1991).

In addition, windbreaks and line plantings can be integrated easily into existing horticulture and animal production systems and provide additional economic benefits to the landowner (Brandle et al. 1992b). It is possible to include marketable products (specialty products, ornamentals) into windbreaks or to manage them for wildlife and integrate them in fee hunting schemes. In addition, they can be incorporated into suburban and urban settings as part of edible landscapes, for wildlife plantings, or refuges for diverse species, and to reduce land fragmentation effects.

One obstacle to establishment or renovation of windbreaks has been the lack of cost-share incentive programs to help defray landowner costs. Lack of awareness of windbreak features in the landscape means more educational programs are needed for professionals and landowners about windbreak technologies and how they can be used to increase incomes - through yield increases, potential for reduced impacts of pests and diseases, and planning for harvestable products. Thus, there is a need to develop species recommendations and economic fact sheets for windbreak benefits to crop and animal production. This education will necessitate formulation of management guidelines for the region and specific situations.

\section{Special Applications}

There are a great variety of practices that can be termed special applications of agroforestry in the U.S. They go by a multitude of names that may differ from place to place and in how they are carried out. In addition, their practices may overlap with that of other agroforestry practices, or involve a combination of various agroforestry practices.
One of the most appealing special applications may be the inclusion of woody plants on farms as landscape corridors for wildlife habitat and movement (Tanner 2002) (Figure 7). These corridors provide valuable habitat for wildlife, birds and insects, and can help diminish the fragmentation of forest habitat as well as increase aesthetic value of the area (NAC 1998). They may also serve to enhance land value and valuation of property by prospective buyers. Another example is the production of short rotation woody biomass, such as poplars, which can be promoted as a component for treatment of animal waste lagoons (Kuhn \& Nuss 2000). These and other tree applications can serve as visual screens or as barriers to decrease effects of odor or noise around farmlands and urban interfaces (Tyndall \& Colletti 2002; Wright \& Ranney 1991).

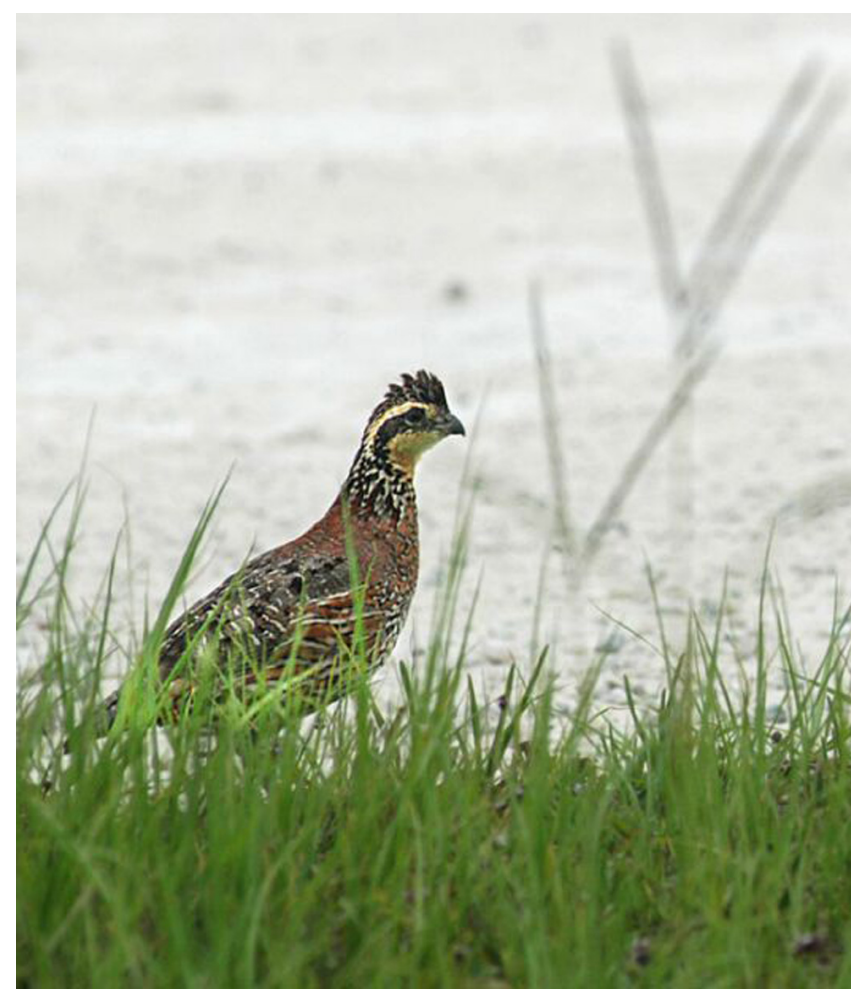

Figure 7. Agroforestry applications include wildlife corridors for species such as bobwhite quail. Credits: Larry Korhnak. Used with permission.

Special applications can be applied in fruit production as well. Basically, fruit orchards that are in the establishment phase can be used for intercropping forage, row, or vegetable crops during the first few years (Beetz 2002; Diver \& Ames 2000; Garrett \& McGraw 2000). Deciduous fruits, found across the region in southern Georgia and Alabama 
and northern Florida, can do well in this special application, as can numerous species and varieties of fruits in central and southern Florida (Orfanades et al. 2001; Andersen et al. 2000; Crocker \& Williamson 1994). These applications can also be combined with windbreaks to enhance fruit production. Carambolla (Averrhoa carambola L.), for example, which needs wind protection, is often grown as a patch within another fruit tree crop, such as avocado (Persea americana) (Crane 1994). Blueberries may also be incorporated into this type of system, although they are seasonal and have technology limitations (Williamson \& Lyrene 1997).

Many other applications are possible. Grapes have been combined with vegetable crops (David et al. 1993) or animals in alley cropping. And honeybees have long been combined with citrus orchards and on farms for crop pollination (Alexander \& Alexander 2002; Sanford 1988, 2000).

There are numerous other tree-crop combinations. At the Kenari Grove in Palm Beach County, Florida, for example, lychee (Litchi chinensis) and longan (Dimocarpus longan) are grown with banana (Musa sp.) and plantain (Plantago spp.) as windbreaks, and some pommelo (Citrus maxima), with wax melon (Benincasa hispida), roselle (Hibiscus sabdariffa), and lemon grass (Cymbopogon citratus), among other specialty intercrops (pers. observation). Edible landscapes (Josiah 2001a) and multi-strata patio or homegardens are increasingly popular, especially among urban residents. Participants in programs such as Master Gardeners and Neighborhood Yards and Gardens also cultivate butterfly garden species and other specialty plants to increase wildlife habitat and diversity in urbanized settings.

\section{Perceptions of Agroforestry from the Field}

National efforts to assess the potential of agroforestry (Garrett et al. 1994) and collect information on the status of agroforestry practices in the regions of the U.S. (Merwin 1997; Shultz et al. 1995) indicate the need for research to be regional and site specific. Regional and local information is necessary to determine how to design or integrate agroforestry practices under prevailing conditions (AFTA 2000).

Accordingly, beginning in the spring of 2001, CSTAF extension staff began to document observations of agroforestry practices in use throughout the southeastern region (Workman et al. 2002a). Information was gathered from field observations, interviews with extension agents, foresters, university faculty, and from farm visits with producers. These initial observations helped in formulation of the agroforestry opinion polls for the extension program. The information gathered will be helpful in tailoring research, professional training for technology transfer, and extension programs to assist landowners in adopting agroforestry.

Agroforestry practices observed in the southeastern USA in 2001 during CSTAF field activities, are shown in Table 2.

According to the CSTAF survey of natural resource professionals, streamside management zones or woody riparian buffers were the most widely observed practice in Alabama, Florida and Georgia. Overall, almost one-half of the professional respondents indicated they knew over 20 landowners who used streamside buffer practices. The next most observed practices were patio or homegardens, especially in Florida, with about one-fourth of professionals indicating they knew over 20 people using the practice. Just as many respondents, however, knew no one who uses this multi-strata garden practice. Forest farming and nontimber forest products were also prominent, most notably in Georgia where $28 \%$ of the professionals knew 20 or more people involved in this activity.

Florida landowners responding to a question about practices identified patio gardens as their most widely used practice (48\%) and windbreaks (46\%) as the second most widely used. Streamside management zones or woody riparian buffers $(27 \%)$ and silvopasture (26\%) were used by approximately one-fourth of the landowners. A smaller percentage, $14 \%$, managed alley cropping or forest farming of nontimber forest products. 
Table 2. Agroforestry practices observed in the southeastern USA during CSTAF field activities, 2001

\begin{tabular}{|c|c|}
\hline Alley Cropping & $\begin{array}{l}\text { Pecans (Carya illinoensis) with hay and/or clover } \\
\text { Pecans with peaches (Prunus persica L.) for first 10-12 years } \\
\text { Vegetables or perennial peanut in alleys during pecan or citrus establishment } \\
\text { Ornamentals with blueberries (Vaccinium corymbosum L.) } \\
\text { Fruit or nut (e.g., persimmon, Diospyros virginiana L., or chestnut, Castenea dentata (Marshall) } \\
\text { Borkh.) with intercrop (e.g., vegetables or cut flowers) }\end{array}$ \\
\hline Forest Farming & $\begin{array}{l}\text { Pine straw; } N \text { and } P \text { fertilization increase straw } \\
\text { Farmer to chef - herbs, mushrooms, specialty vegetables } \\
\text { Growing edible and medicinal mushrooms (e.g., on melaleuca) } \\
\text { Ferns under natural woodland (e.g., laurel oak, Quercus laurifolia Michx.) shade } \\
\text { Saw palmetto (Serona repens (W. Bartram) Small) management on native woodland range } \\
\text { Ornamentals under shade trees } \\
\text { Honey bees (apiculture) and wildflowers grown for seed } \\
\text { Native medicinals/botanicals grown under forest shade: mosses, Queen's delight, mints, } \\
\text { mushrooms }\end{array}$ \\
\hline $\begin{array}{l}\text { Riparian Forest } \\
\text { Buffers }\end{array}$ & $\begin{array}{l}\text { Including shrubs and trees for wildlife use and bee forage } \\
\text { Managed timber or short rotation woody crop } \\
\text { Managed along streamsides and in farm drainage ravines for special products (NTFP) } \\
\text { Shrubs and trees with deeper roots to aid nutrient absorption } \\
\text { Artificial wetlands/woody buffers for animal waste lagoons (including fish ponds) }\end{array}$ \\
\hline Silvopasture & $\begin{array}{l}\text { Bermuda (Cynodon dactylon (L.) Pers.) and bahia (Paspalum notatum Flüggé) with pines } \\
\text { Winter grazing under pecans } \\
\text { Poultry litter and manure application on tree/pasture } \\
\text { Forage crops for cow/calf or fodder for confined operation } \\
\text { Pastured poultry and free range with tree shade and in fruit orchards } \\
\text { Fruit trees with animal pasture/hay } \\
\text { Livestock-and -fruit for biogas on family farm } \\
\text { Planting of plant browse species along fence lines } \\
\text { Cattle, sheep or goats with trees managed for shade }\end{array}$ \\
\hline $\begin{array}{l}\text { Windbreaks } \\
\text { (Line Plantings) }\end{array}$ & $\begin{array}{l}\text { Border plantings for vineyards } \\
\text { Around citrus or other orchards } \\
\text { For protection from frost } \\
\text { Avocado (Persea americiana Mill.) for carambola (Averrhoa carambola L.) (needs wind protection) } \\
\text { Palms on bunds in flooded rice (field rotation with vegetables) } \\
\text { Planting along lot lines increases assessed land value at sale } \\
\text { As barriers against pesticide drift, odor, noise, dust, or roadsides } \\
\text { Protection of animals from ocean winds and excess salt }\end{array}$ \\
\hline $\begin{array}{l}\text { Special } \\
\text { Applications }\end{array}$ & $\begin{array}{l}\text { Shade for buildings, chicken houses and fish ponds } \\
\text { Fruit trees combined with gardens, ponds and as bee forage } \\
\text { Blackberries (Rubus spp.) for fruit, as live fence and wildlife habitat, and in firebreak areas } \\
\text { Fruit (e.g., citrus) under trees (e.g., live oak) for frost protection } \\
\text { Cereal/mast species around tree plantations with fee hunting } \\
\text { Planting and managing mast species for wildlife and human consumption (e.g., plums, Prunus } \\
\text { spp., mayhaw, Crategus aestivalis (Walter) Torr. \& A. Gray) and as field borders }\end{array}$ \\
\hline
\end{tabular}

\section{Reasons for Adoption of Agroforestry}

The reasons landowners are motivated to adopt agroforestry practices in the U.S. (NARC\&DC 2000) and specifically in the southern states (Merwin 1997; Zinkhan \& Mercer 1997) rank in order from: 1) improved on-farm economics and economic gain, 2) multiple land use management and income diversification, 3) site suitability and erosion control, 4) shortened wait and increased regularity of income, increased return to labor, increased diversification and enhanced timing of cash flow, and 5) support of 
conservation and environmental concerns. The main environmental concerns noted by those surveyed were improved water quality, wildlife habitat and soil erosion control.

Results from a survey by the National Association of Resource Conservation and Development (RC\&D) Councils (NARC\&DC 2000) showed that silvopasture, riparian buffers, and special agroforestry applications were the most widely recognized practices in Alabama, Florida and Georgia. The RC\&D staff surveyed noted various issues addressed by these agroforestry practices in the three states (see Figure 8). Of the overall 115 councils in 28 states that responded, 52\% reported special agroforestry applications in their work areas. More than one-third of these areas were in the Southeast. These professionals identified eight issues that special agroforestry applications can address: Animal Waste, Dust, Municipal Waste, Noise, Odor, Community Interface/Greenbelts, Visual Screening, and Wood Fiber (NARC\&DC 2000). Visual screening and community interface/greenbelts were the most common practices (greater than 50\% frequency), followed by agroforestry for noise control (34\%), municipal waste, animal waste, dust, and odor management (all about 20\%).

The RC\&D survey showed similar results for silvopasture and riparian buffer practices. Wildlife habitat and water quality, specifically non-point source pollution, were the issues both practices address along with soil erosion control. Farm economics figured prominently for silvopasture (see Figure 8). These responses echo results from the earlier survey by Zinkhan and Mercer (1997) for the southern states and indicate specific issues that agroforestry addresses.

\section{Perceived Benefits of Agroforestry}

CSTAF used opinion polls as instruments to gauge existing knowledge, practice, and information needs of professionals and landowners in Alabama, Florida, and Georgia (Workman et al. 2002a). In the 2001 survey of natural resource professionals, extension and forestry personnel were presented a list of 16 potential benefits of agroforestry and asked to rank the importance (1 lowest to 5 highest) of the benefits in their work areas (see Figure 9). Results
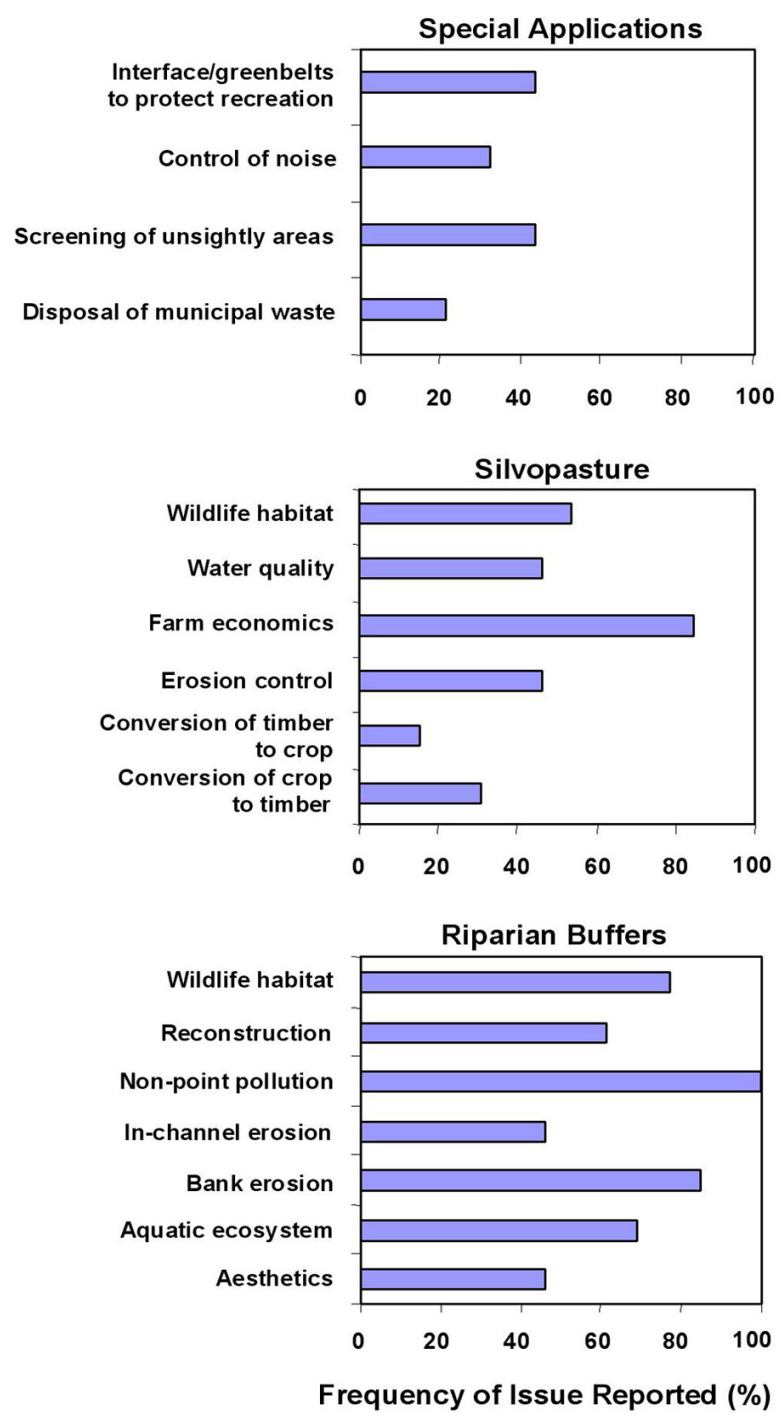

Figure 8. Perspectives of RC\&D staff on issues addressed by their three most observed agroforestry practices in Alabama, Florida and Georgia. Data showing the frequency of each issue reported are from a survey with USDA NAC. Graphs represent percentage of respondents $(n=39)$. Adapted. Credits: NARC\&DC 2000. Adapted.

were similar to earlier surveys (NARC \& DC 2000; Zinkhan \& Mercer 1997) in that wildlife habitat (mean rank 4.2 out of a maximum of 5) and water quality (4.1) were top ranked as important potential benefits, with influence on water quantity (4.0), and long term investment (3.9) not far below. The only significant difference between the viewpoints was that professionals in Florida perceived soil conservation as less of a benefit than their peers in Alabama and Georgia.

Florida landowners responding to the same question on a similar but separate survey stated improvement of appearance and atmosphere 


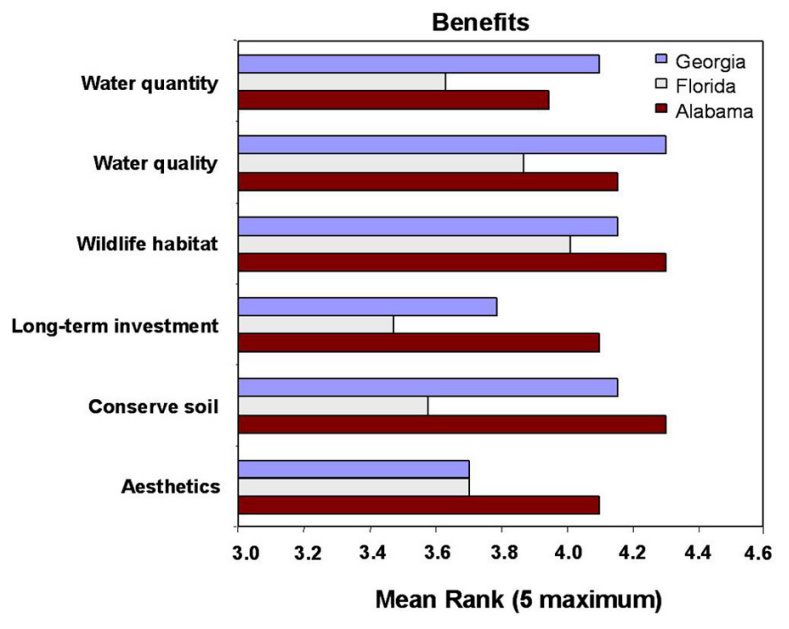

Figure 9. Most important agroforestry benefits as ranked by natural resource professionals in the states of Alabama, Florida, and Georgia in a 2001 survey by CSTAF $(n=212)$. Credits: CSTAF. Used with permission.

(aesthetic) value (82\%) and shade for livestock (78\%) were the most important benefits of agroforestry (see Figure 10). Improvement of wildlife habitat and soil conservation (70\% each), long-term investment return and increased biological diversity (65\% each), increase in land value (59\%), more interesting farm (56\%), water quantity $(55 \%)$ and water quality (54\%) were also viewed of high importance by greater than fifty percent of the landowners.

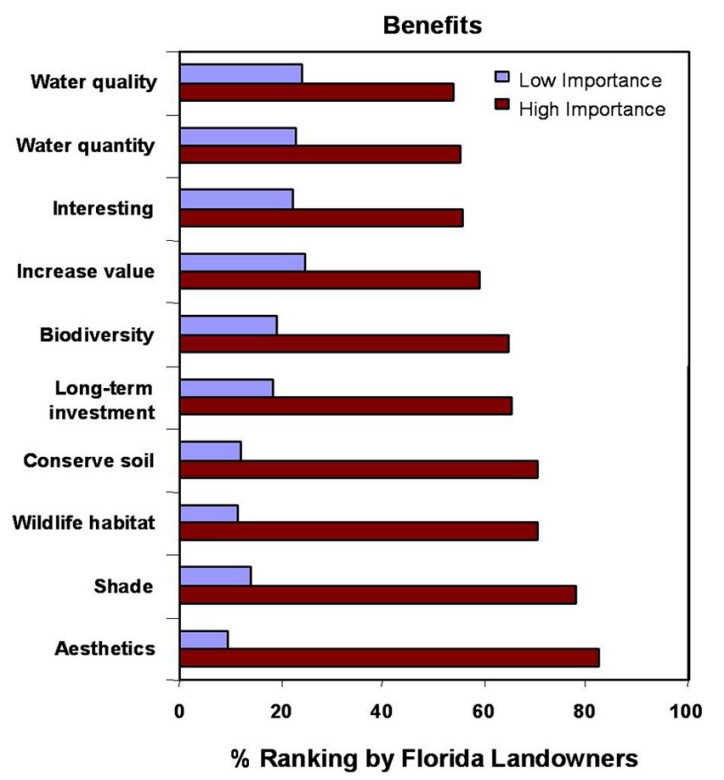

Figure 10. Florida landowner ranking of the importance of agroforestry benefits (top 10 of 16) in a 2001-2002 survey by CSTAF $(n=165)$. Credits: CSTAF. Used with permission.

\section{Perceived Constraints to Use of Agroforestry}

Constraints to adoption of agroforestry practices that have been noted in literature include lack of management skills and technical knowledge; incompatibility between multiple outputs; high establishment or annual management costs; negative impacts of livestock on tree seedlings and soil productivity (Cannon 1998; Zinkhan \& Mercer 1997; Kettler 1995; Barnes 1984; Lewis 1984); potential for weedy species and pest interactions (Dix et al. 1999); economic planning for intensity and timing of inputs and outputs; meager institutional and policy support including finances and incentives (Buck 1995; Kettler 1995; Muller \& Scherr 1990); and market development, landowner information and public education (Kurtz 2000; NARC\&DC 2000; Kettler 1995). The valuation of non-market benefits or non-economic values is evident to many practitioners and motivates a number to implement practices; however, it is often a constraint at higher levels of institutional and social policy (Merwin 1997).

When asked about potential constraints to agroforestry, professionals responding to the 2001 CSTAF survey ranked lack of familiarity with the practices and the lack of demonstrations (overall mean rank 3.8 and 3.7) as most important (see Figure 11). Lack of information and markets ranked next highest in importance (3.6 each). Influence on water quantity, fire risk, and lack of seed were not seen as important constraints. Of the 108 written responses to open-ended questions about constraints, across the three states, a total of $33 \%$ of the professionals reiterated the lack of information, knowledge and demonstrations of successful agroforestry.

Profitability and money concerns, including the cost of investment, possibility of cost-sharing or other incentives, and the level of return were mentioned by $17 \%$. From 9 to $11 \%$ of the respondents noted land use conversion, increased development, industrialization of farms, and encroaching suburbia as concerns.

The 2001 survey of Florida landowners (34\%) specified competition between crops, trees and animals as the greatest constraint to use of 


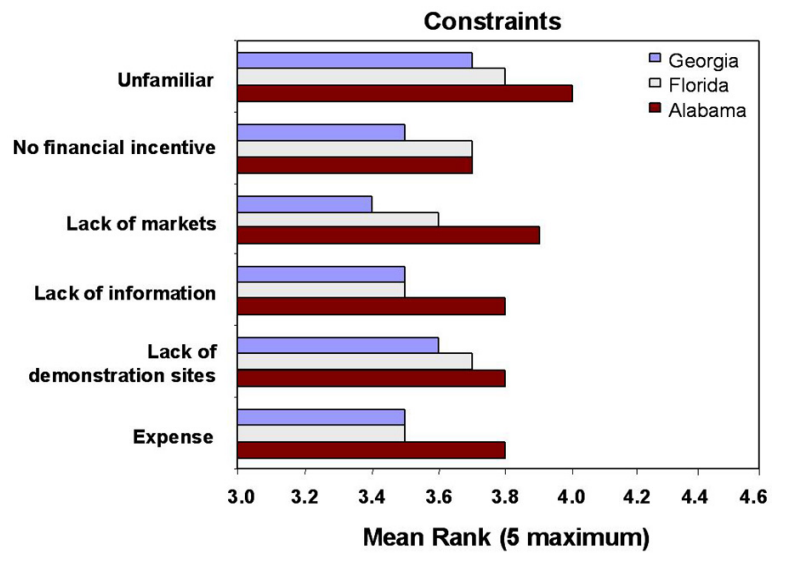

Figure 11. Most important constraints to use of agroforestry as ranked by natural resource professionals in the states of Alabama, Florida, and Georgia in a 2001 survey by CSTAF $(n=212)$. Credits: CSTAF. Used with permission.

agroforestry (see Figure 12). Lack of information and lack of markets were equally important constraints (33\%), followed by expense of additional management $(31 \%)$ and lack of familiarity with the practices (30\%). Landowners indicated lack of technical assistance (29\%), water quantity (27\%), and lack of demonstrations (26\%) were also important concerns.

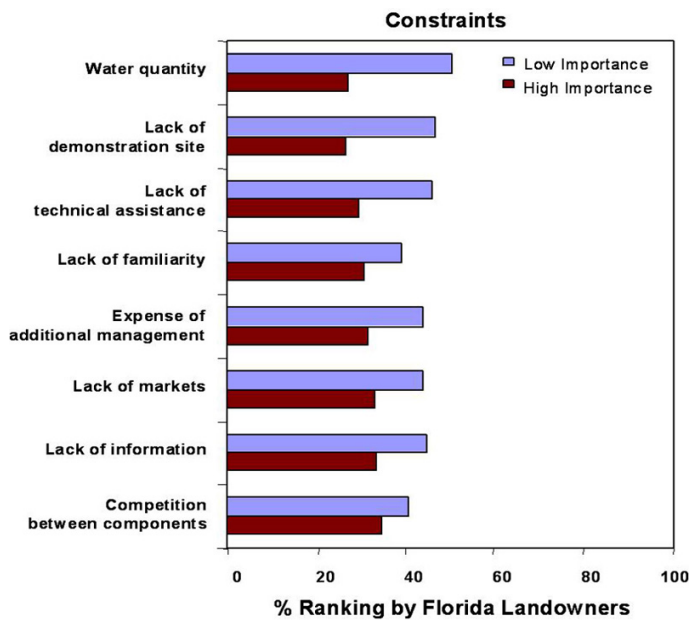

Figure 12. Percentage of Florida landowners indicating specific constraints about the use of agroforestry practices in a 2001 CSTAF opinion poll $(n=165)$. Credits: CSTAF. Used with permission.

\section{Methods for Overcoming Constraints}

In 1995, the Southeastern Agroforestry Workshop explored possibilities and constraints for agroforestry in the region by bringing together extension, research, and policy-making representatives. The working groups made key recommendations on how to overcome management, ecological, economic, and policy constraints to agroforestry adoption by landowners (Kettler 1995). Major recommendations included:

- synthesis of information on current practices;

- identification of research needs and designs that provide economically viable options;

- attention to agroforestry potential for urban/rural interface; and

- collaborative on-farm testing of technologies.

The groups pointed out the need for compatibility of farming system components, management for pest species and waste management, adapting known agronomic and silvicultural practices to address soil and water limitations, and outlining adaptive management based on understanding multiple input-output processes.

Participants acknowledged the lack of information about and familiarity with agroforestry. The groups agreed organizational and governmental support, such as federal programs for local research and technical assistance, could provide subsidies that would be needed if costs and risks, real and perceived, are greater than economic returns and benefits to landowners. The workshop emphasized agroforestry's potential to furnish greater opportunities and economic diversity to landowners provided that trained extension personnel and an institutional home for agroforestry exist. These ideas echo nascent thoughts on agroforestry in the southern United States that were expressed in an earlier workshop in Louisiana a decade before (Abruzzese \& Byington 1984; Linnartz \& Johnson 1984).

A 1998 agroforestry conference at Alabama A\&M University held for Exploring Agroforestry Opportunities in the South was developed under the premise that more farmers would be willing to try agroforestry if they knew how to make it successful (Cannon 1998). There were 22 presentations that reviewed research on agroforestry practices begun over the previous decade. The specific research and 
experiences presented at that conference pointed out the continued need to document how defined agroforestry combinations work under stated conditions, what benefits and economic considerations exist, and what cultivation and scheduling details can be recommended. A major limitation to adoption was seen as lack of well-documented local agroforestry experiments and positive experiences (Cannon 1998).

\section{Resources for Farmers and Landowners}

Farmer willingness to spend more time on farm management and learning new skills is limited (Israel $\&$ Ingram 1990). Since many farmers also have off-farm employment, unless it is compelling and preferably convenient, most will not attend special functions or devote additional time to collecting information about land management options though the majority of landowners welcome information to help them improve their enterprises. In 1990 many preferred to receive information by mail (Israel 1990; Israel \& Ingram 1990) though according to the CSTAF assessments, many can now access it via the Internet. With the number of landowners heavily reliant on a single or few (e.g., cattle and/or timber) production options on their agricultural land, using northern Florida as an example (Israel 1990; Israel \& Ingram 1990), diversification through use of agroforestry technologies could provide greater income stability. The landowners that express concerns about their time and capital available for investment need information and assistance in learning how to evaluate which alternatives suit their needs. Many look to Cooperative Extension and the State Forestry agencies or other trusted sources for information to guide their decisions.

\section{Role of Extension and Forestry Professionals}

Extension and forestry professionals are interested in developing skills to serve the needs of their clientele and tend to concentrate their efforts on topics of highest demand. Agroforestry technologies must first be recognized as relevant and applicable to clientele needs, since they are only one set of tools in a suite of several that can be called upon to offer land managers. Then the technologies must be delivered in ways appropriate for given circumstances. This means professionals are continually faced with integrating knowledge from various disciplines with their personal experiences and observations. Training in agroforestry, therefore, must offer professionals background knowledge of how tree-animal and tree-crop combinations can be advantageous for local circumstances.

Professional training must be advertised through effective networks to publicize learning opportunities and be offered at convenient times for participants. Since in-service training programs for extension and forestry professionals are coordinated through their state agencies/institutions, (e.g., university and county offices), one- to two-day workshops could be delivered at several district locations throughout each state. Additional "agroforestry modules" could be included in mini-conferences and field days held by various state major programs, (e.g., small farms, sustainable agriculture, pest management, silviculture), or included in programs with Federal, (e.g., NRCS, ARS), private, (e.g., Heifer Project, The Nature Conservancy, Audubon), or professional partner groups, (e.g., Soil and Water Conservation Chapters, Society of American Foresters). These events could also utilize demonstration sites run by university experiment stations and by farmers.

The interest by landowners seeking viable production alternatives, along with the increasing body of knowledge from agroforestry education and research activities, calls for training, technology transfer programs, outreach, and extension activities in agroforestry. Universities in Alabama, Florida, Georgia and Mississippi have agroforestry education and research programs supported by disciplines such as anthropology, landscape architecture, biological systems, botany, horticulture, soil science, animal science and aquaculture. In this regard, agroforestry education fits into the larger philosophy for helping students learn conservation as part of their life's studies (AFTA 2002; Rietveld \& Workman 1998; Lassoie et al. 1994; Orr 1991; Jacobson 1990; Nair et al. 1990).

Auburn University, Clemson University, Mississippi State University, University of Florida, 
and University of Georgia, for example, have strong forestry and agriculture programs in the region. In addition, Tuskegee University (Solaiman \& Hill 1991) and sister programs at Florida A\&M (Onokpise et al. 2002) and Alabama A\&M (Brown 2001), have programs focused on small ruminant production in agroforestry. Other institutions in the southern U.S. and Caribbean, e.g., University of Missouri, Texas A\&M, Virginia Polytechnic Institute and State University, and University of the Virgin Islands, have agroforestry technology transfer programs and publications. Much of this research and technology transfer is undertaken in partnerships with federal and state agencies.

The USDA Cooperative State Research, Education and Extension Service, the National Agroforestry Center, Forest Service, Natural Resources Conservation Service, Agricultural Research Service, Resource Conservation and Development Councils (NARC\&DC) and State Forestry agencies are central players in the collection and dissemination of research results through technology transfer activities, public services, and education programs for landowners and managers. Their efforts are visible with their presence in each state and territory in the region. State agencies, in addition, have a large role in delivery of information to landowners and citizens in rural and urban settings.

\section{Information and Decision Support Systems}

Landowners, farmers and professionals need useful information about different agroforestry opportunities and tree species of potential use in agroforestry designs. Landowners as well as extension, forestry, and natural resource professionals need specific geographical information for good land use planning and management.

CSTAF's online Geographical Information System (GIS) compiles valuable information on soils, vegetation, land use, and property information that landowners and professionals can freely access. The online database is part of the Agroforestry Information System begun with a prototype Decision Support System (DSS) developed at the county level in Florida. The Agroforestry Information System includes an agroforestry tree/shrub database, the working prototype of the Southeastern Agroforestry Decision Support System, SEADSS (Ellis 2001; Ellis et al. 2000), a collection of agroforestry readings, and a photo gallery.

The evolving Tree/Shrub Database is starting out with Florida's woody species that will expand in geographic scope to cover the Southeastern Coastal Plain. The subtropical tree and shrub database contains plant descriptions, information on ecology and site adaptability, management and propagation, and economic and environmental uses of the species. There is user access to both text descriptions and photos.

The SEADSS utilizes GIS technology to enable the client to select a location of interest that is linked to spatial data on climate and soil characteristics for the state of Florida. The application incorporates a plants database as described above. Being a prototype, the application is built with a modular and flexible framework in which spatial data of different scales and/or regions as well as plant data may be easily added to or modified as necessary.

The information will provide decision-support assistance to landowners, extension agents, foresters, and researchers for agroforestry development and investigation using Internet resources, GIS, and database management systems. The DSS component will offer computer-based tools that integrate GIS with a tree and shrub database and agroforestry features to assess on site characteristics, potential practices, and suitable tree/shrub species. These tools can be used for tree and shrub selection and evaluation on specific soil types, land areas, or properties that are geo-referenced through the GIS. The purpose is to educate the public and to provide landowners and professionals easy Internet access to agroforestry information and planning tools for the subtropical zone.

\section{Networks, Community-Based Conservation, and Regional Outreach}

The emerging pattern of linking farmers within an area together through an information network supports the idea of community-based conservation in action. Farmers and rural residents with similar aspirations to maintain their livelihood can support 
and inspire one another toward innovation and stewardship. Together they scrutinize how to utilize their resources in ways that benefit them not only as individuals, but also benefit their communities. The more successful and diversified the area farms, the more diversified and available the income. The increased income availability generates consumer capital and opportunities for community members to further develop consumer and farm-oriented specialty trades. This means the rich mix of livestock, timber, and crop production generated by agroforestry practices can be complemented by a diverse and robust mix of related non-agricultural activities for both individual and community benefits. These agroforestry and related activities can also be tailored to youth and offered through 4-H programs, projects with schools and community groups, and other extension and CSTAF partner affiliates.

The vision for development of agroforestry within the sustainable agriculture and forestry networks calls for skills in several disciplines. Cooperation between soil, plant, and animal scientists in collaboration with economic and education specialists has been the logical first step. The core CSTAF group has benefited from interaction with scientists in the horticultural and forest sciences, farming systems, veterinary sciences, and extension specialists. Increased interaction with scientists with anthropological, livestock, wildlife, and water management expertise could be of great benefit to the CSTAF activities. Graduate student involvement has increased research effort, especially in quantification of physiological interactions in agroforestry settings and applications for organic methods. There are a number of additional themes ripe for graduate and undergraduate projects throughout the region, including work on specific agroforestry practices, species combinations, agroforestry extension, market analysis and development with producers, and involvement in the Virgin Islands or other subtropical areas.

Additional opportunities can be shaped with extension of materials and future interactions within the Caribbean Basin. The CSTAF component in the U.S. Virgin Islands will serve as a starting point for development of practices and technology transfer in the Caribbean. Activities there can draw upon, complement, and further experiences on neighboring Puerto Rico with a vision for outreach to other island nations in the Caribbean. The strength of Caribbean programs at the University of Florida and the ties and interest between the Atlantic and Gulf Coastal region with the Caribbean can promote development of more international exchange activities for CSREES and other USDA agencies. This opportunity can serve as a platform for greater utilization of CSREES strengths in extension methodologies, program development, and human capacity building in the Caribbean region. The process can serve as a model for international outreach and technology transfer methods and programs.

\section{Agroforestry: What Does the Future Hold?}

To date, interest in agroforestry has been most concentrated in universities and has only just begun to filter into public programs in the last ten years. Two formative workshops in the Southeast (Kettler 1995; Cannon 1998) drew interested parties together and fomented action in the region. Since that time, infrastructure and dissemination mechanisms specific to agroforestry have been pioneered by universities and government entities, specifically by the USDA NAC and NRCS (e.g., NRCS 1997), with partner groups in the South and Southeast. With the establishment of CSTAF in 2001 (Nair \& Bannister 2001), several institutions in the Southeast are undertaking some of the much-needed basic, applied, and multi-disciplinary research in agroforestry. Along with its research component, CSTAF plans to develop extension training materials in agroforestry to complement existing technology transfer documents for agroforestry and, in collaboration with other institutions working in the region, provide technical "in-service" training to natural resources professionals in the principles, technologies and opportunities unique to agroforestry.

\section{Policy Considerations}

Many landowners may be fearful of risking loss of agricultural transfer payments or coming under added restrictions on their farm or forestry operation imposed by new practices and enterprises (Merwin 1997). Cost share and incentive programs can help 
promote integrative technologies, conservation goals, and adoption of agroforestry (Cutter et al. 1999; SCS 1991). However, policies for trade and taxation to support farmland, agricultural income, labor productivity, and market access (APP 2001; Durst \& Monke 2001) must be formulated and implemented to protect and conserve natural resources and rural vitality as part of sustainable development and ecosystem health for the region.

Agroforestry must also consider current forestry policies and conditions. The trend of decline in timber prices has resulted from recent trade agreements and increased food and fiber importation from Canada, South America, and other regions of the world. Though economical for supply of current need on a national scale, trade policy has distinct consequences about land use here in the southeastern U.S. What incentive do private owners have to invest in replanting for commercial production?

Landowners are faced with decisions on how to hold and manage their land or to sell to a commercial developer, timber company, or find another alternative land use. Removal of pine stocks currently exceeds growth on forest industry and non-industrial private lands in the South (Prestemon \& Abt 2002). Projections for increasing softwood plantations from the approximately $30 \mathrm{mil}$ ac of today to about $48 \mathrm{mil}$ ac by 2040 was recently reported in the U.S. Forest Service Southern Forest Resource Assessment. It is predicted much of this production will shift away from the increasingly urbanized eastern sector of the region into Mississippi and the western sector of the Atlantic and Gulf Coastal Plain (SRS 2002; Prestemon \& Abt 2002).

Some combination of tax incentives, development rights acquisition, and regulation to protect farmland from rising urban pressures, exists in all fifty states. Information on agricultural protection zoning and if/how it makes a difference, how land use choices are influenced by right-to-farm laws, and the consequences, both economic and social, of urban growth boundaries or other regulations to manage growth, are available to decision makers at local and state levels (ICMA 2002).
The current political atmosphere is conducive to implementation of good land use planning, conservation, and education and youth programs. A Bush administration policy initiative, for example, outlined in February 2002 commits America to a strategy to cut greenhouse gas emissions by $18 \%$ over the next 10 years (Bierly \& Eden 2002). The Farm Security and Rural Investment Act of 2002 increases conservation funding by $80 \%$ over 1996 levels and much of this is focused on management of working lands. The Commodity Credit Corporation (CCC) mandated in the law calls for funding technical assistance by public and private sector providers (SWCS 2002).

One avenue for these federal appropriations, the Conservation Reserve Program (CRP), remains the single largest program funded. The program has expanded options for economic use and creates opportunity for land restoration and retirement gains. It contains provisions for Biomass Pilot Projects for harvesting plant material to be used for energy production from enrolled lands (SWCS 2002). Through the CRP, farmers can receive cost-share assistance and annual rent payments to establish long term cover that will help conservation efforts on eligible land. As in the 2002 Farm Bill, conservation efforts will benefit from congressional support and growing citizen demand for sustaining natural resources.

Programs for cost-share incentives on private lands to date have included the Forestry Incentive Program, the Conservation Reserve Program, the Wetlands Reserve Program, the Stewardship Incentives Program, the Environmental Quality Incentives Program, and the Wildlife Habitat Incentives Program (Groh 2002). The new Forest Land Enhancement Program (FLEP), established by the 2002 Farm Bill replaces several of these programs and provides for agroforestry support. The Environmental Quality Incentives Program (EQIP), the Wetlands Reserve Program (WRP), Farmland Protection Program (FPP), Wildlife Habitat Incentives Program (WHIP) and the Conservation Security Program (CSP), among others, can now be used by states in more flexible ways to coordinate implementation of multiple conservation programs. The CSP provides some balance to the 
commodity-based subsidies in providing stewardship-based entitlements. The CSP compensates producers who have invested in conservation and is tied to environmental performance (SWCS 2002). Policy studies at regional levels are needed to determine how agroforestry practices fit into land use policy application, and how analyses of decision-making and adoption on the part of landowners can feed back into policy formulation (Kurtz 2000; Mercer \& Miller 1997; Henderson 1991). See Appendix 2 for a list of agroforestry resources on the Web. Also see Appendix 3 for a list of agroforestry incentive programs for Alabama, Florida and Georgia.

\section{Economic Considerations}

Agroforestry practices begin with a model and then develop in different directions according to how the farmers adapt the model to their own natural resource and socio-economic situations. This means agroforestry development can take some time, and certainly different practices will be adopted or adapted at different rates. The farmer and land manager determines whether goals are met over time at a reasonable cost based on private cost-effectiveness and management value (Kurtz 2000; Soule et al. 2000; Lohr 1995; Kidd \& Pimentel 1990). Considerations of cash and labor inputs, management and returns, and marketing need documentation in order to provide land managers with decision-making information. Limited diversity of farm enterprises makes the farm vulnerable to environmental and economic changes. Thus, alternatives for generating income, such as agroforestry, could provide greater stability and more balanced income flows for small farm size operators.

Many economic cost-benefit studies have demonstrated that agroforestry technologies such as alley cropping, forest farming, riparian buffer strips, silvopasture, and windbreaks, can generate a positive private rate of return higher than conventional agriculture or forestry enterprises (Kurtz 2000; Garrett et al. 2000; Clason 1995; Brandle et al. 1992b). Outputs can also be characterized as non-revenue generating yields such as "public goods" or environmental services.
Research is underway to assess market and non-market goods and services of agroforestry systems as well as estimate multiplier effects and distributive impacts of agroforestry. A factor analysis methodology was tested by CSTAF researchers to measure respondent's preferences and rank the magnitude of their impact for silvopasture in southern Florida (Shrestra \& Alavalapati 2002). The first application of this methodology to agroforestry showed promise for its use by decision-makers in targeting factors critical to adoption. Additional studies on hunting revenues relative to silvopasture and peoples willingness to pay for environmental services will provide information for other economic valuations of the market and non-market benefits of agroforestry. A social accounting matrix to measure the economic spin-off effects of agroforestry and an economic model to quantify the effects of carbon sequestration associated with agroforestry practices are being utilized and further developed.

These economic studies along with the series of economic analyses programmed for the CSTAF research components can help provide information on profitability of agroforestry practices (Alavalapati et al. 2002). Farmers who are willing to learn about the options for new enterprise development, including value-added products and custom specialty products, are better able to overcome barriers to adoption of alternative production systems.

\section{What Specific Accomplishments Can Be Made?}

Though we know that agroforestry will not replace most agricultural and forestry practices across the region, it is worthwhile to consider how agroforestry technologies can be incorporated into each at various geographical scales. Agroforestry practices have application potential over a range of land area sizes, from individual plots to total periphery of large park areas, from buffering and restoration of degraded sites to partitioning municipal landholdings, and, as envisioned for the Mississippi River watershed, to serve as riparian buffer zones to guard against non-point source pollution and sedimentation. These integrated land use practices can help bridge the gaps in the mosaic of land uses across the region and serve as tools to strengthen the 
sustainable supply of goods and environmental services needed by society. Given that farming and plantation forestry have been rural economic mainstays against other development options in the region, ways to improve their value as a viable land use will continue to support rural communities and offer greater future land use flexibility.

From the needs assessment conducted by CSTAF and the local knowledge documented, along with information generated from the research and experiences of partner organizations, there are abundant models to build on for successful training endeavors for students and professionals. Excellent training endeavors for professionals have been led by USDA, Alabama A\&M University, the FASAT group at the University of Georgia, and the Forest Stewardship, Fire Toolkit, and Small Farms programs at Florida A\&M University and the University of Florida. Plans and materials for similar training efforts for agroforestry practices are being considered by CSTAF in the southeastern U.S.

Technology transfer needs for all practices call for region-specific information for design decisions, compatibility of components, production budgets, marketing opportunities, economic analysis, and effectiveness models (AFTA 2000). Technical designs must balance input availability, quality and timing with production outputs, and their processing and markets for various components. Results from research and landowner experiences can be formulated into materials useful in training professionals and in developing technology transfer materials they can use with their clientele.

In alley cropping and windbreak designs, as in other practices, there is a need to identify suitable tree species, determine optimum spacing along with tree and crop management practices, and measure effects of management on yields, tree growth, soil parameters and economic returns. "An investment of time and resources to develop appropriate management practices for economic trees and annual crops could make alley cropping a profitable venture for farmers in the South" (Shannon \& Isaac 1998:2).
We also need to compile information on which shade tolerant species have economic potential for forest farming and nontimber forest products in the region. Studies to document their growth and management requirements and determine market strategies with producers can help sustain the practices. Of unique interest is the recognition of "patio" or "dooryard" gardens by professionals. The patio or dooryard garden, or homegarden, a form of multistrata agroforestry, has not been included in the set of temperate agroforestry practices acknowledged in North America. However, the popularity of multistrata agroforestry in the region likely reflects not only the subtropical climate of the region but also the rich diversity of practices brought to the States by people with heritage from African, Asian, Caribbean and Latin American tropical areas.

There is information available about benefits of riparian forest buffers and streamside management zones thanks to the local Soil and Water Conservation Districts, State Forestry offices, USDA-ARS Southeast Watershed Research Laboratory, the Alabama Department of Environmental Management, Florida Department of Environmental Protection, and the Georgia Department of Natural Resources that work with the Environmental Protection Agency, and other professional groups in the region. These studies help provide the scientific basis for designing buffers to meet an expanding set of landowner and societal objectives. There is continuing opportunity for greater application of riparian buffer technologies, based on identified management goals.

Currently, water quality management goals aim to protect aquatic habitats, drinking water and recreation areas, prevent erosion and flooding, buffer pollution, and prevent eutrophication of surface waters and contamination of groundwater. These goals are addressed through state and federal programs that include agroforestry options (Bosch et al. 1997; Wade \& Tucker 1996) to help reduce nutrient and sediment loads reaching natural drainage waters. Fertilization and crop rotation management as well as water drainage-storage-reuse and pump management under irrigation will also help safeguard water quality in the Coastal Plain (Berndt et al. 1998). 
Thus, given the information available, we need to compile results about design and placement criteria and how riparian buffers can meet conservation and production objectives. Best management practices for streamside zones and cost share programs are in place to help restore impaired streams and to promote maintenance and establishment of buffers and constructed wetlands (e.g., EPA 319). CSTAF collaborators can contribute research results on sediment control and reduction in phosphorus and nitrate loadings by agroforestry practices. In addition, there is great potential to design decision support tools to help on-farm performance and selection of species. We need further investigation and demonstration of viable species combinations and vegetation zonation to include short rotation woody species and specialty crops of value that have potential to increase buffer width and diversity. Available information must be developed into formats that facilitate use by resource managers and landowners to promote greater adoption of the practices (AFTA 2000).

In silvopasture, possibilities exist for integration of browse species for both small ruminants and cattle into existing farm plans. New studies with native browse species in Florida and trials with introduced species, such as those with paulownia conducted in North Carolina (Mueller et al. 2001), are underway. Since silvopasture technologies are applicable on a wide range of scales, they are readily adaptable for all sizes of land holdings and for various combinations of animal and plant species.

The materials from regional institutions and the USDA national center (NAC) are currently in use for a series of dynamic silvopasture workshops throughout the Southeast (Robinson et al. 2001). The NRCS and cooperators at Land Grant institutions have initiated a network for silvopasture training with State Cooperative Extension and Forestry professionals. These institutions, including CSTAF, are preparing the way for demonstration sites in the region, which can provide landowners with training and information on appropriate silvopastoral practices.

Lastly, landowners interested in incorporating recreational or scenic criteria into their multiple-use management and stewardship plans (Hubbard et al. 1999; Stein 1998) can utilize agroforestry practices in their design objectives. Streamside management zones, and edges of harvested forest, pasture, or crop fields are ideal places to include wildlife plantings, hedgerows or hiking and horse trails. Windbreaks and fencerow plantings provide additional alternatives for wildlife habitat. Seasonal activities or year round opportunities for wildlife viewing and nature study can be enhanced with plantings that also serve conservation purposes. Incomes from hunting and recreation uses for diversification are increasing in popularity. Land leases for hunting and fee hunting and fishing can provide continuous or seasonal cash flow. These activities are compatible with forest harvesting regimes that provide a diversity of forest age classes and habitats across the landscape, and streamside/riparian buffer zones that provide wildlife cover and movement corridors (Schaefer \& Brown 1992).

\section{Concluding Remarks}

Agroforestry has the potential to improve environmental quality as well as the diversity and productivity of an agricultural system. These improvements may enhance cash flows to farm families and provide good return for the labor invested. These practices may also moderate temperature and other environmental stresses as well as provide settings for recreational uses. Compared to traditional plantation forestry or agricultural systems, agroforestry techniques provide opportunities to diversify incomes, expand production, and enhance non-market benefits such as soil and water conservation and wildlife habitat.

However, successful adoption of agroforestry practices requires careful planning and management to effectively integrate different trees, crops and animals. In light of the objectives presented in this white paper, farmers and other landowners are encouraged to experiment with the agroforestry practices described in this paper, and to adapt them to their own particular locations and production goals. In turn, feedback from these farmer-initiated activities will be of great benefit in helping define the impetus and direction of agroforestry for the future. 
Appendix 1. English-to-Metric Conversions

Table 3. English-to-metric conversions

\begin{tabular}{|lll|}
\hline \hline English Units & Conversion & Metric Units (S.I.) \\
\hline LENGTH & & \\
\hline feet $(\mathrm{ft})$ & $\times 0.3048=$ & meters $(\mathrm{m})$ \\
\hline miles $(\mathrm{mi})$ & $\times 1.6093=$ & kilometers $(\mathrm{km})$ \\
\hline AREA & & \\
\hline miles $^{2}\left(\mathrm{mi}^{2}\right)$ & $\times 2.59=$ & kilometers $^{2}\left(\mathrm{~km}^{2}\right)$ \\
\hline acres $(\mathrm{ac})$ & $\times 0.4047=$ & hectares $(\mathrm{ha})$ \\
\hline VOLUME & & \\
\hline gallons $(\mathrm{gal})$ & $\times 3.7854=$ & liters $(\mathrm{l})$ \\
\hline MASS & & \\
\hline pounds $(\mathrm{lb})$ & $\times 0.4536=$ & kilograms $(\mathrm{kg})$ \\
\hline tons $(2000 \mathrm{lb})$ & $\times 907.18=$ & kilograms $(\mathrm{kg})$ \\
\hline \hline
\end{tabular}

\section{Appendix 2. Agroforestry Resources on the Web}

\section{ORGANIZATIONS AND AGENCIES}

Alternative Farming Systems Information Center (AFSIC), National Agricultural Library, USDA: http://www.nal.usda.gov/afsic/AFSIC_pubs/ altlist.htm

Association for Temperate Agroforestry (AFTA): http://www.aftaweb.org

Center for Subtropical Agroforestry (CSTAF), University of Florida: http://cstaf.ifas.ufl.edu/index.htm

Educational Concerns for Hunger Organization (ECHO): http://www.echonet.org/

Forest Garden Initiative (FGI): http://www.forestgarden.org/

National Agroforestry Center (NAC), USDA: http://www.unl.edu/nac/

Natural Resources Conservation Service (NRCS), USDA: http://www.nrcs.usda.gov/technical/ECS/forest/
National Sustainable Agriculture Information Service (NSAIS), Appropriate Technology Transfer for Rural Areas (ATTRA), USDA: http://attra.ncat.org/

University of Missouri Center for Agroforestry (UMCA): http://agebb.missouri.edu/umca/index.htm

Winrock International (WI): http://www.winrock.org/forestry/factnet.htm

World Agroforestry Centre (WAC): http://www.worldagroforestrycentre.org/home.asp

\section{INCENTIVE PROGRAMS}

"Building Better Rural Places" (ATTRA): http://attra.ncat.org/guide/

002 Farm Bill--Incentives for Agroforestry" (NAC): http://www.unl.edu/nac/ia/winter03/winter03.pdf

"Funding Incentives for Agroforestry in Missouri" (UMCA):

http://agebb.missouri.edu/umca/pubs/fundincent.pdf

"Southern-Region Competitive Grants Program" (USDA Sustainable Agriculture Research and Education program (SARE)): http://www.griffin.peachnet.edu/sare/homepage.shtml

\section{Appendix 3. Agroforestry Incentive Programs for Alabama, Florida and Georgia}

Numerous incentive programs exist on a national and state level for the encouragement of agroforestry and agroforestry-related practices, such as riparian buffers, alley cropping, forest farming, and habitat restoration. While not comprehensive, the following is a brief list of specific resources and contact information for residents of Alabama, Florida and Georgia. (Information in this section was compiled by Ms. Danelle Harrison for CSTAF.)
ALABAMA
1. Alabama Agriculture and Conservation Development Commission Program 
The Alabama Agriculture and Conservation Development Commission administers state-funded conservation incentive programs. Various agroforestry-related practices are eligible for grants, including permanent vegetative cover establishment, buffer strip crop systems, terrace systems, cropland protective cover, conservation tillage, riparian buffer systems, forest farming, tree stand improvement, and silvopasture agroforestry practices.

Contact: Alabama Forestry Commission, 513 Madison Avenue, Montgomery AL 36104. Phone: (334) 240-9300. OR USDA-Alabama Natural Resources Conservation Service, PO Box 311, 3381 Skyway Drive, Auburn, AL 36830. Phone: (334) 887-4500; Fax: (334) 887-4551.

\section{Alabama Openland Tree-Planting Cost-Share Program}

The Alabama Openland Tree-Planting Cost-Share Program (OTP) provides financial assistance for tree planting, site preparation, and competition control measures on open land, available at a 75 percent reimbursement rate for landowners.

Contact: Alabama Forestry Commission (above) OR your local Alabama Power office.

\section{Alabama Wildlife Habitat Incentives Program (WHIP)}

The WHIP program sponsors practices aimed at restoration of native grasses, provision of habitat for the bobwhite quail and other grassland nesting species, restoration of fire-dependent ecosystems, and protection of fish and shrimp living in areas sensitive to agricultural pollutants.

Contact: Alabama Natural Resources Conservation Service (above).

\section{Cost Share Program for Farm, Pasture, or Woodland}

The Cost Share Program for Farm, Pasture, or Woodland provides financial and technical assistance for landowners of farms, pastures, or woodlands. The program offers 60 percent cost share for landowners to plant trees or to install other conservation equipment and to develop practices that help reduce soil erosion. The program is administered by the Soil and Water Conservation Committee and run by local Soil and Water Conservation Districts on a county level.

Contact: Soil and Water Conservation Committee, PO Box 304800, Montgomery, AL 36130-4800. Phone: (334) 242-2620; Fax: (334) 242-0551.

\section{Partners for Fish and Wildlife}

Partners for Fish and Wildlife supports implementation of conservation strategies to protect ecologically sensitive areas on private lands, such as the Cahaba River basin. Supported projects include wetland restoration, riparian vegetation systems in silvopasture, protection of endangered species, and control of exotic species.

Contact: Partners for Fish and Wildlife Service, US Fish and Wildlife Service, 4270 Norwich Street Extension, Brunswick, GA 31520-2523. Phone: (912) 265-9336, ext. 25; Fax: (912) 265-1061.

\section{FLORIDA}

\section{Florida Farm and Ranch Lands Protection} Program

The Florida Farm and Ranch Lands Protection Program (FRPP) has provided support to farmers and ranchers who implement practices that preserve topsoil, improve water quality, and limit non-agricultural uses of the land. Landowners interested in FRPP can implement alley cropping, forest farming, and silvopasture under this program.

\section{Contact: local Florida Cooperative Extension} Service units.

\section{Florida Wetlands Reserve Program}

The Florida Wetlands Reserve Program (WRP) provides technical and financial assistance to eligible landowners to restore, enhance and protect wetlands that have been altered agriculturally, including pasture and forestry practices. One of its main focuses is to provide habitat for wildlife migratory birds, particularly those that are threatened and endangered. The other main focus is to improve water 
quality by removing nutrients, reducing phosphorus loads, improving stream base flow which reduces temperature, dissolved oxygen, and salinity problems in downstream waters. Landowners interested in agroforestry can install buffers and alley cropping systems.

Contact: Wetlands Reserve Program Coordinator, Natural Resources Conservation Service. Phone: (352) 338-9509.

\section{Florida Wildlife Habitat Incentives Program (WHIP)}

The Florida Wildlife Habitat Incentive Program provides funding for landowner practices that benefit plant and animal species living in strategic habitat conservation areas, early successional/grassland habitats, and neotropical migrant bird habitats. Landowners interested in this program can implement forestry practices such as buffer zones and alley cropping. Partners in this program are: Florida Game and Fresh Water Fish Commission, U.S. Fish and Wildlife Service, Quail Unlimited, Soil and Water Conservation Districts, and Florida Natural Resources Conservation Service.

Contact: Florida NRCS. Phone: (352) 338-9544.

\section{Partners for Fish and Wildlife}

The Partners for Fish and Wildlife Program is an initiative developed to provide technical and financial assistance to private landowners and other partners who conduct habitat restoration and improvement activities on their land. The focus of the program in Florida is on restoration of native habitats, restoration of degraded streams and wetlands, and eradication of invasive, exotic species. Assistance is awarded to landowners in conservation programs administered by the USDA under the 2002 Farm Bill (e.g.,

Wetlands Reserve Program and Conservation Reserve Program).

Contact: State Coordinator, PFW, 6620 Southpoint Drive South, Suite 310, Jacksonville, FL 32216-0912. Phone: (904) 232-2404, ext. 120; Fax: (904) 232-2404.

\section{GEORGIA}

\section{Bobwhite Quail Initiative}

The Bobwhite Quail Initiative is directed toward providing nesting and brood rearing habitats for quail in Georgia. Landowners receive incentive payments for the establishment and maintenance of certain types of early successional habitat.

Contact: BQI Headquarters, DNR Wildlife Resources Division, BQI, 116 Rum Creek Drive, Forsyth, GA 31029. Phone: (478) 994-7583.

\section{Federal Program Information}

The 2002 Farm Bill provided several changes that affect and benefit agroforestry. The Environmental Quality Incentives Program (EQIP) provides cost-share incentives for a number of conservation practices. Practices that can address these priority concerns, including silvopasture and other forestry and agroforestry practices, are eligible for funding.

Contact: Resource Conservationist, USDA-NRCS, 355 East Hancock Ave., Athens, GA 30601. Phone: (706) 546-2061.

\section{Georgia Reforestation to Enhance Environmental Needs}

Georgia Power Company and the Georgia Forestry Commission (GFC) provide financial assistance for tree planting on open land to landowners with ten or more acres. Cost-share assistance is provided at a flat rate and covers the cost of trees, planting, prescribed burning, subsoiling, mowing, and chemical spraying. This program can be used to implement alley cropping and forest farming practices.

\section{Contact: local Georgia Forestry Commission} office.

\section{Georgia Wildlife Habitat Incentives Program (WHIP)}

The Georgia Wildlife Incentives Program is geared mainly towards the restoration of longleaf pine ecosystems and early successional plant systems along with many other habitats of special concern. Some of its priority programs include wildlife upland 
habitat management, wildlife wetland habitat management, prescribed burning, riparian buffers, field borders, wetland creation and restoration, hedgerow plantings, and tree/shrub planting. Partners in the Georgia WHIP plan include Georgia Department of Natural Resources, and Wildlife Resource Division's Private Land Initiative.

Contact: Georgia Natural Resources Conservation Service. Phone: (706) 546-2114.

\section{Partners for Fish \& Wildlife}

The Partners for Fish and Wildlife Program assists private landowners with fish and wildlife habitat restoration on their land. In Georgia, the program has focused on the restoration of the longleaf pine habitat, restoration of degraded streams and riparian areas, and restoration and improvement of endangered, threatened, and rare species habitat.

Contact: Partners for Fish and Wildlife Program, U.S. Fish and Wildlife Service, 4270 Norwich Street Extension, Brunswick, GA 31520-2523. Phone: (912) 265-9336, ext.25; Fax: (912) 265-1061.

\section{Wild Turkey Woodlands Program}

The National Wild Turkey Federation along with the Georgia Forestry Commission through Georgia's Forest Stewardship Program implements the Wild Turkey Woodlands Program. The program certifies landowners who manage their lands for wild turkey. Landowners interested in agroforestry can use the discount seed program to offset the costs of forest farming, alley cropping, and planting windbreaks or riparian buffers.

Contact: The National Wild Turkey Federation, Phone: (803) 637-3106; E-mail: HYPERLINK "mailto:nwtf@nwtf.net"nwtf@nwtf.net.

\section{Literature Cited}

Abernathy, V. and R.E. Turner. 1987. US forested wetlands: 1940-1980. Bioscience 37:721-727.

Abruzzese, J.R. and E.K. Byington. 1984. Patterns and trends in farm agroforestry in the
Southcentral United States, pp. 53-64 In N.E. Linnartz and J.J. Johnson (eds.) 33rd Annual Forestry Symposium: Agroforestry in the Southern United States. Louisiana State University Agricultural Center, Baton Rouge, LA.

AFTA, Association for Temperate Agroforestry. 2000. Agroforestry in the United States: Research and technology transfer needs for the next millennium. Association for Temperate Agroforestry, Columbia, MO.

AFTA, Association for Temperate Agroforestry. 2004. Education, Research and Technology Transfer. http://www.aftaweb.org/entserv1.php?page=32

Ainslie, W.B. 2002. Forested Wetlands. Chapter 20, p. 479-499 In D.N. Ware and J.G. Greis (eds.) Southern Forest Resource Assessment. USDA Forest Service GTR SRS-53.

Alavalapati, J.R.R., R. Shrestha, G. Das, and K. Stephan. 2002. Economic Benefits of Agroforestry Systems. Available by Center for Subtropical Agroforestry, School of Forest Resources, University of Florida. http://cstaf.ifas.ufl.edu.

Alexander, A.G. and S.J. Alexander. 2002. Case Study: Native U.S. plants in honey and pollen production. pp. 223-236 In E.T. Jones, R. McLain, and J. Weigand (eds.) Nontimber Forest Products in the United States. University Press of Kansas, Lawrence, KS.

Alexander, S.J., J. Weigand, and K. Blattner. 2002. Nontimber forest product commerce. pp. 115-150 In E.T. Jones, R. McLain, and J. Weigand (eds.) Nontimber Forest Products in the United States. University Press of Kansas, Lawrence, KS.

Allen, S.C. 2003. Nitrogen dynamics in a pecan (Carya illinoensis K. Koch)-cotton (Gossypium hirsutum L.) alley cropping system in the southern United States. Ph.D. Dissertation, University of Florida, Gainesville, FL.

Altieri, M.A. 1991. Increasing biodiversity to improve insect pest management in agroecosystems, pp. 165-181, In D. L. Hawksworth (ed.) The Biodiversity of Microorganisms and Invertebrates: 
Its Role in Sustainable Agriculture. CAB

International, Wallingford, UK.

Andersen, P., J. Williamson, and T. Crocker. 2000. Sustainability Assessment of Fruit Crops for North and North Central Florida. Factsheet HS765, a series of the Horticultural Sciences Department. Florida Cooperative Extension Service, Institute of Food and Agricultural Sciences, University of Florida.

APP, Agriculture Policy Project. 2001. Making Changes: Turning Local Visions into National Solutions. Funded by the W.K. Kellogg Foundation. Agriculture Policy Project. Henry A. Wallace Center for Agricultural \& Environmental Policy at Winrock International, Arlington, VA.

Ashton, M.S. and F. Montagnini (eds.). 1999. The silvicultural basis for agroforestry systems. CRC Press, Boca Raton, FL. 278 p.

Bagley, W.T. 1988. Agroforestry and windbreaks. Agric. Ecosyst. Environ. 22/23:583-591.

Baker, L.A. 1998. Design considerations and applications for wetland treatment of high-nitrate waters. Water Sci. Tech. 38:389-395.

Baker, J.C. and W.C. Hunter. 2002. Effects of forest management on terrestrial ecosystems. Chapter 4, p. 91-112 In D.N. Ware and J.G. Greis (eds.) Southern Forest Resource Assessment. USDA Forest Service GTR SRS-53.

Barnes, R.F. 1984. Summary and overview of agroforestry in the Southern United States, pp. 175-185 In N.E. Linnartz and J.J. Johnson (eds.) 33rd Annual Forestry Symposium: Agroforestry in the Southern United States. Louisiana State University Agricultural Center, Baton Rouge, LA.

Baughman, M.J. (ed.). 1996. Proceedings of the Symposium on Nonindustial Private Forests: Learning from the Past, Prospects for the Future. Conference, February 1996. Washington, DC. Proc. Published by Minn. Ext. Serv., St. Paul, MN.

Bean, J. 2002. Maximizing your forestland's potential: Alternative income opportunities from forestland. Forest Landowner 61 (2): 35-38.
Beetz, A. 2002. Agroforestry Overview. Horticulture Systems Guide. National Sustainable Agriculture Information Center: Appropriate Technology Transfer for Rural Areas (ATTRA). Fayetteville, AR.

http://attra.ncat.org/attra-pub/PDF/agrofor.pdf.

Belonogova, T. 1993. Changes in blueberry and cowberry yields under the influence of forestry measures. Aquilo Ser. Bot. 31:17-20.

Benjamin, T.J., W.L. Hoover, J.R. Seifert, and A.R. Gillespie. 2000. Defining competition vectors in a temperate alley cropping system in the midwestern USA: 4. The economic return of ecological knowledge. Agrofor. Syst. 48:79-93.

Bennett, B.C. and J.R. Hicklin. 1998. Uses of saw palmetto (Serenoa repens, Arecaceae) in Florida. Econom. Bot. 52 (4):381-393.

Berndt, M.P., H.H. Hatzell, C.A. Crandall, M. Turtora, J.R. Pittman, and E.T. Oaksford. 1998. Water quality in the Georgia-Florida Coastal Plain, Florida and Georgia, 1992-96: U.S. Geological Survey Circular 1151 http://water.usgs.gov/pubs/circ1151/.

Bierly, E.W. and H.F. Eden. 2002. Atmospheric and Ocean Sciences in the FY2003 Budget. AAAS Report XXVII, Research and Development FY2003. American Association for the Advancement of Science. http://www.aaas.org/spp/rd/03pch15.htm.

Bird, P.R. 1998. Tree windbreaks and shelter benefits to pasture in temperate grazing systems. Agrofor. Syst. 41:35-54.

Bliss, J.C., S.K. Nepal, R.T. Brooks Jr., and M.D. Larsen. 1997. In the mainstream: Environmental attitudes of mid-south NIPF owners. South. J. Appl. Forestry 21:37-42.

Bonilla C.A., J.F. Munoz and M. Vauclin. 1999. Opus simulation of water dynamics and nitrate transport in a field plot. Ecol. Model. 122:69-80.

Bonsi, C., E. Rhoden, A. Woldeghebriel, P. Mount, S. Solaiman, R. Noble, G. Garis, C. McMahon, H. Pearson, and B. Cash. 1991. Kudzu-goat interactions - a pilot study. pp. 84-90 In 
G. Solaiman and W.A. Hill (eds.) 1991. Using goats to manage forest vegetation: A regional inquiry. Workshop Proceedings. Tuskegee University Agricultural Experiment Station, Tuskegee, AL.

Bosch, D.D., R.A. Leonard, C.C. Truman, L.T. West, and D.W. Hicks. 1997. Impacts of conventional agricultural practices on aquifer water quality: An overview of the Plains, Georgia water quality study. pp. 504-507 In K. Hatcher (ed.) Proceedings of the 1997 Georgia Water Resources Conference. Univ. of Georgia, Athens.

Brandle, J.,T. Wardle, and G. Bratton. 1992a. Opportunities to increase tree planting in shelterbelts and the potential impacts on carbon storage and conservation. Chapt. 9, Forests and Global Change, Vol. 1. R.N. Sampson and D. Hair (eds.) American Forests.

Brandle, J.R., B.B. Johnson, and T. Akeson. 1992b. Field windbreaks: Are they economical? J. Prod. Agric. 5:393-398.

Brandle, J.R., L. Hodges, and J. Stuthman. 1994. Windbreaks and specialty crops for greater profits. pp. 81-91 In W.J. Rietveld, (ed.) Proc. Symp. Agroforestry and Sustainable Systems. U.S. For. Serv. Gen. Tech. Rep. RM-GTR-261. Rocky Mountain For. Range Exp. Stn., Ft. Collins, CO.

Brandle, J.R., L. Hodges, and B. Wight. 2000. Windbreak practices. pp. 79-118, In H.E. Garrett, W.J. Rietveld, and R.F. Fisher (eds.). North American Agroforestry: An Integrated Science and Practice. American Society of Agronomy, Madison WI.

Bransby, D.I., S.E. Sladden, D.D. Kee, and N.E. West. 1996. Forage yield response of mimosa (Albizia julibrissin) to harvest frequency. pp. 64-65 Rangelands in a sustainable biosphere. Proceedings of the Fifth International Rangeland Congress. Vol. 1. Society of Range Management, Salt Lake City, UT.

Brantley, S. 1998. Planning silvopastoral systems in southeastern USA. pp. 9.1-9.6 In P.G. Cannon (ed.). Exploring agroforestry opportunities in the South. Southern Agroforestry Conference sponsored by the Natural Resources Conservation Service, the US Forest Service, and Alabama A\&M University. Oct. 1998. Huntsville, AL.

Brauer, D. and D. Burner. 2001. Pine straw and nuts. Dale Bumpers Center, USDA Agricultural Research Service. mall Farms Research News, Winter 1:1-4.

Brown, G. 2001. Center for Forestry and Ecology. Available by Alabama A\&M University, School of Agricultural and Environmental Sciences, Department of Plant and Soil Science. http://saes.aamu.edu/ sps/Forestry.html.

Buck, L.E. 1995. Agroforestry policy issues and research directions in the US and less developed countries: Insights and challenges from recent experience. Agrofor. Syst. 30:57-73.

Buck, L.E. 1999. Forest farming with ginseng: A study of plant ecology, quality, and market relations. p. 67 In J.P. Lassoie and L.E. Buck (eds.). Exploring the opportunities for agroforestry in changing rural landscapes. Proc. 5th Conf. on Agroforestry in North America, Ithaca, NY, Aug 1997. Cornell University, Ithaca.

Bugg, R.L., M. Sarrantonio, J.D. Dutcher, and S.C. Phatak. 1991. Understory cover crops in pecan orchards: Possible management systems. Am. J. Altern. Agric. 6:50-62.

Burel, F. 1996. Hedgerows and their roles in agricultural landscapes. Crit. Rev. Plant Sci. 15:169-190.

Burton, N.L. and A.D. Scarfe. 1991. Angora goats in Alabama woodlands. pp. 78-83 In G. Solaiman and W.A. Hill (eds.) 1991. Using goats to manage forest vegetation: A regional inquiry. Workshop Proceedings. Tuskegee University Agricultural Experiment Station, Tuskegee, AL.

Byrd, N.A., C.E. Lewis, and H.A. Pearson. 1984. Management of southern pine forests for cattle production. USDA Forest Service, Southern Region, General Report R8-GR4. 22p. 
Campbell, F.T. 1997. Testimony for oversight hearing on resident exotic plants and pests threatening the health of our national forests. Given before the House of Representatives, Subcommittee on Forests and Forest Health on June 24, 1997. http://www.house.gov/resources/105cong/forests/ jun24.97/campbell.htm. [Accessed on 10 April 02].

Cannon, P.G. 1998. Exploring agroforestry opportunities in the South. Southern Agroforestry Conference sponsored by the Natural Resources Conservation Service, the US Forest Service, and Alabama A\&M University. Oct. 1998. Huntsville, AL.

Carroll, R. 1995. Environmental policy and sustainable rural land use: What is the appropriate scale? p. 7 In J.S. Kettler (ed.) Southeastern Agroforestry Workshop: Exploration of Possibilities and Constraints. Workshop Proceedings, September 1995, Athens, GA. University of Georgia and USDA Natural Resources Conservation Service.

Cary, A. 1928. On management of turpentine forests. Weekly Naval Stores Review, reprints, Savannah, GA.

Chamberlain, J. and A.L. Hammett. 1998. Non-timber forest products: The other forest products. Forest Prod. J. 48:10-19.

Chamberlain, J. and A.L. Hammett. 2002. Non-timber forest products: Alternatives for landowners. Forest Landowner 61 (2):16-18.

Clason, T.R. 1995. Economic implications of silvipastures on southern pine plantations. Agrofor. Syst. 29:227-238.

Clason, T.R. 1999. Silvopastoral practices sustain timber and forage production in commercial loblolly pine plantations of northwest Louisiana. Agrofor. Syst. 44:293-303.

Clason, T.R. and S.H. Sharrow. 2000. Silvopastoral practices. pp. 119-147 In H.E. Garrett, W.J. Rietveld, and R.F. Fisher (eds.) North American Agroforestry: An Integrated Science and Practice. American Society of Agronomy, Madison WI.
Colletti, J., C. Mize, R. Schultz, A. Skadberg, J. Mottila, R. Hall, L. Rule, P. Wray, M. Thompson, I. Anderson, and D. Buxton. 1991. Land application of sludge to forest and herbaceous energy crops. pp. 327-338 In H.E. Garrett (ed.). Proc. 2nd Conference on Agroforestry in North America. Springfield, MO, Aug. 1991. University of Missouri, Columbia.

Colletti, J., C. Mize, R. Schultz, R. Faltonson, A. Skadberg, J. Mottila, M. Thompson, R.Scharf, I. Anderson, C. Accola, D. Buxton, and R. Brown. 1994. An alley cropping biofuels system: Operation and economics. pp. 303-310 In R.C. Schultz and J.P. Colletti (eds.). Proc. 3rd Conference on Agroforestry in North America: Opportunities for Agroforestry in the Temperate Zone Worldwide. Ames, IA, Aug, 1993. Iowa State University, Ames.

Conner, R.C. and A.J. Hartsell. 2002. Forest Area and Conditions. Chapter 16, pp. 357-401 In D.N. Ware and J.G. Greis (eds.) Southern Forest Resource Assessment. USDA Forest Service GTR SRS-53.

Conner, W.H., N.L. Hill, E.M. Whitehead, [and others]. 2001. Forested wetlands of the Southern United States: a bibliography. USDA Forest Service, Southern Research Station, General Technical Report SRS-043.

Cordell, H.K., J.C. Bliss, C.Y. Johnson, and M. Fly. 1998. Voices from southern forests. Trans. 63rd No. Am. Wildl. and Natur. Resour. Conf.: 332-347.

Correll, D.L. 1983. N and P in soils and runoff of three coastal plain land uses. pp. 207-224 In R. Lowrance, L. Assmussen, and R. Leonard (eds.) Nutrient Cycling in Agricultural Ecosystems. University of Georgia Special Publication No. 23. Athens, GA.

Crane, J.H. 1994. The Carambola (Star Fruit). Fact Sheet HS-12, a series of the Horticultural Sciences Department. University of Florida, Tropical Research and Education Center.

Crocker, T.E. and J.G. Williamson. 1994. Dooryard Fruit Varieties. Fact Sheet HS-23, a series of the Horticultural Sciences Department, Florida Cooperative Extension Service, Institute of Food and Agricultural Sciences, University of Florida. 
Cutter, B.E., A.I. Rahmadi, W.B. Kurtz, and S. Hodge. 1999. State policies for agroforestry in the United States. Agrofor. Syst. 46 (3):217-227.

Daily, G. (ed.). 1997. Nature's services: Societal dependence on natural ecosystems. Island Press, Washington, DC.

Dangerfield, C.W. and R.L. Harwell. 1990. An analysis of a silvopastoral system for the marginal land in the southeast United States. Agrofor. Syst. 10:187-197.

Daniels, R. B. and J.W. Gilliam. 1996. Sediment and chemical load reduction by grass and riparian filters. Soil Sci. Soc. Am. J. 60:246-251.

David, P.P., D.K. Bonsi, E.G. Rhoden, and V.A. Khan. 1993. An economic evaluation of alley cropping grapes with selected vegetable crops. J. Small Fruit and Viticulture 1:37-47.

Davis, J.M. 1993. Goldenseal: Cultivation of a rare botanical. Hortscience 28 (5):151.

Demurs, J.A. Ferguson. 1997. Medicinal ethnobotany in North Florida. M.S. Thesis, University of Florida, Gainesville, FL.

Diver, S. 2001. Bamboo: A multipurpose agroforestry crop. Horticulture Production Guide. National Sustainable Agriculture Information Center: Appropriate Technology Transfer for Rural Areas (ATTRA). Fayetteville, AR.

Diver, S. and G. Ames. 2000. Sustainable Pecan Production. Horticulture Production Guide. National Sustainable Agriculture Information Center: Appropriate Technology Transfer for Rural Areas (ATTRA). Fayetteville, AR.

Dix, M.E. 1991. Distribution of arthropod predators of insect pests in and near windbreaks. Proceedings of the Second Conference on Agroforestry In North America. Association for Temperate Agroforestry. August 18-21, 1991, Springfield, MO.

Dix, M.E. 1996. Pest management in agroforestry systems. J. Forestry 94:8-12.
Dix, M., D. Hill, L. Buck, and W. Rietveld. 1997. Forest Farming: An Agroforestry Practice. Agroforestry Notes AF Note - 7. USDA National Agroforestry Center.

Dix, M.E., B. Bishaw, S.W. Workman, M.R. Barnhart, N.B. Klopfenstein, and A.M. Dix. 1999. Pest management in energy- and labor-intensive agroforestry systems. pp. 131-155 In L.E. Buck, J.P. Lassoie, and E.C.M. Fernandes (eds.) Agroforestry in Sustainable Agricultural Systems. CRC Press, Lewis Publishers, Boca Raton, FL.

Dosskey, M., R. Schultz, and T. Isenhart. 1997a. Riparian Buffers for Agricultural Land. Agroforestry Notes AF Note - 3. USDA National Agroforestry Center.

Dosskey, M., R. Schultz, and T. Isenhart. 1997b. A Riparian Buffer Design for Cropland. Agroforestry Notes AF Note - 5. USDA National Agroforestry Center.

Dronen, S.I. 1988. Layout and design criteria for livestock windbreaks. Agric. Ecosyst. Environ. 22/23:231-240.

Duke, J.A. 1997. The green pharmacy. Rodale Press, Emmaus, PA.

Durst, R. and J. Monke. 2001. Effects of federal tax policy on agriculture. Food and Rural Economics Division, Economic Research Service, USDA Agricultural Economic Report 800.

Duryea, M.L. (ed.). 1988. Alternative enterprises for your forest land: forest grazing, Christmas trees, hunting leases, pine straw, fee fishing, and firewood. School of Forest Resources and Conservation, Florida Cooperative Extension Service, IFAS Circular No. 810. University of Florida, Gainesville. 30p.

Duryea, M.L. 2000. Pine straw management in Florida's forests. Circular 831. School of Forest Resources and Conservation, Florida Cooperative Extension Service, Institute of Food and Agricultural Sciences, University of Florida.

Duryea, M.L. and S.W. Vince. 2001. The Wildland-Urban Interface: Balancing Growth with 
Natural Resource Management and Conservation. November 5-8, 2001, Conference. School of Forest Resources and Conservation, University of Florida. p. 26 Introduction to the Wildland-Urban Interface. http://conference.ifas.ufl.edu/urban/abstracts.pdf.

Ellis, E. 2001. System for selecting agroforestry trees for the Southeast United States. Ph.D.

Dissertation. School of Forest Resources and Conservation, University of Florida, Gainesville, FL.

Ellis, E.A., P.K.R. Nair, P.E. Linehan, H.W. Beck, C.A. Blanche, and H.M. Rauscher. 2000. A GIS-based database management application for agroforestry planning and tree selection. Computers and Electronics in Agric. 27:1-3.

Ewel, J.J. 1999. Natural systems as models for the design of sustainable systems of land use. Agrofor. Syst. 45 (1-3):1-21.

FAO, Food and Agriculture Organization. 2001. Assessment of the world food security situation. Twenty-seventh Session. Committee on World Food Security. Food and Agriculture Organization of the United Nations. Rome.

FDEP, Florida Department of Environmental Protection. 2003. Surface Water. http://www.dep.state.fl.us/water/surfacewater/ index.htm.

FFGA, Florida Fern Growers Association. 2001. http://www.fl-ag.com/ferns/history.htm.

Felker, P. C.T. Sorensson, D. Ueckert, P. Jacoby, E. Singer, and R. Ohm. 1998. Growth, cold-hardiness, protein content, and digestibility of 70 Leucaena seedlots on three sites in Texas, USA. Agrofor. Syst. 42:159-179.

Fitchen, J.M. 1991. Endangered spaces, enduring places: Change, identity, and survival in rural America. Westview Press, Boulder, CO.

Forman, R.T.T. 1995. Land mosaics: The ecology of landscapes and regions. Cambridge University Press, Cambridge, UK.

Foster, S. 1993. Herbal renaissance. Gibbs-Smith Publ., Salt Lake City, UT.
Garrett, H.E. and W.B. Kurtz. 1983. Silvicultural and economic relationships of integrated forestry farming with black walnut. Agrofor. Syst. 1:245-256.

Garrett, H.E. and R.L. McGraw. 2000. Alley cropping practices. pp. 149-188 In Garrett, W.J. Rietveld and R.F. Fisher (eds.). North American Agroforestry: An Integrated Science and Practice. American Society of Agronomy, Madison WI.

Garrett, H.E., W.J. Rietveld, and R.F. Fisher (eds.). 2000. North American Agroforestry: An Integrated Science and Practice. American Society of Agronomy, Madison, WI.

Garrett, H.E, W.B. Kurtz, L.E. Buck, M.A. Gold, L.H. Hardesty, J.P. Lassoie, H.A. Pearson, and J.P. Slusher. 1994. Agroforestry: An integrated land-use management system for production and farmland conservation. Prepared for USDA SCS 68-3A75-3-134, Resource Conservation Act Appraisal. Association for Temperate Agroforestry, Columbia, MO.

Georgia DNR/EPD, Department of Natural Resources/Environmental Protection Division. 2002. Decades of Change. Report, April 2002. http://www.ganet.org/dnr/environ/gaenviron_files/ annlrpt_files/gaenv02.pdf.

Gillespie, A.R., S. Jose, D.B. Mengel, W.L. Hoover, P.E. Pope, J.R. Siefert, D.J. Biehle, T. Stall, and T.J. Benjamin. 2000. Defining competition vectors in a temperate alley cropping system in the midwestern USA: 1. Production physiology. Agrofor. Syst. 48:25-40.

Gold, M. and L. Godsey. 2002. A framework to analyze markets for traditional and nontraditional midwestern agroforestry products: the case of Eastern Red Cedar. pp. 179-183 In W. Schroeder and J. Kort (eds.) Proceedings of the Seventh Biennial Conference on Agroforestry in North America. August 13-15, 2001, Regina, Sask., Canada.

Grado, S.C., C.H. Hovermale, and D.G. St. Louis. 2001. A financial analysis of a silvopasture system in south Mississippi. Agrofor. Syst. 53:313-322. 
Granskog, J.E., T. Haines, J.L. Greene, B.A. Doherty, S. Bick, H.L. Haney Jr., S.O. Moffat, J. Speir, and J.J. Spink. 2002. Policies, Regulations, and Laws. Chapter 8, pp. 189-223 In D.N. Ware and J.G. Greis (eds.) Southern Forest Resource Assessment. USDA Forest Service GTR SRS-53.

Gray, K. 2001. Alley cropping in Alabama. Association of Research Directors, 1890s Universities, Annual Symposium. Alabama A\&M University.

Groh, T. 2002. Florida's Forestry and Wildlife Cost Share Programs. Available by Florida Division of Forestry. http://www.fl-dof.com/Help/stewardship/ costshare.html.

Hagen, B. von, J.F. Weigand, R. McLain, R. Fight, and H.H. Christensen. 1996. Conservation and development of nontimber products in the Pacific Northwest: An annotated bibliography. USDA Forest Service PNW-GTR-375.

Halls, L.K., G.W. Burton, and B.L. Southwell. 1957. Some results of seeding and fertilization to improve southern forest ranges. USDA Forest Service SE Exper. Stat. Res. Pap. 78. Ashville, NC.

Hammett, A.L. and J.L. Chamberlain. 2002. Greenery - An opportunity for forest landowners. Forest Landowner 61 (2):44-46.

Hart, R.A. 1991. Forest gardening. Green Books, Foxhole, Dartington, UK.

Hart, R.H., R.H. Hughes, C.E. Lewis, and W.G. Monson. 1970. Effect of nitrogen and shading on yield and quality of grasses grown under young slash pines. Agron. J. 62:285-287.

Hawken, P. 1993. The Ecology of Commerce: A declaration of sustainability. HarperCollins Pub., New York.

Henderson, D. (ed.). 1991. Proc. Mid-South Conference on Agroforestry Practices and Policies. Winrock Int. Inst. for Agric. Dev., Morrilton, AR., West Memphis, AR.
Hernandez, H.M. and Y.C. Abud. 1987. The reproductive ecology of trees in a mountain mesophytic forest in Michoacan, Mexico. Boletin de la Sociedad Botanica de Mexico 47:25-35.

Hill, D. 1999. Farming Exotic Mushrooms in the Forest. Agroforestry Notes AF Note -13. USDA National Agroforestry Center.

Hill, D.B. and L.E. Buck. 2000. Forest Farming Practices. pp. 283-320 In H.E. Garrett, W.J. Rietveld and R.F. Fisher (eds.). North American agroforestry: An integrated science and practice. American Society of Agronomy, Madison, WI.

Hill, D.B. and T.C. Webster. 1996. Apiculture and forestry (bees and trees). Agrofor. Syst. 29:313-320.

Howarth, R., D. Anderson, J. Cloern, C. Elfring, C. Hopkinson, R. Lapointe, T. Malone, N. Marcus, K. McGalthery, A. Sharpley, and D. Walker. 1997. Nutrient Pollution of Coastal Rivers, Bays, and Seas. Issues in Ecology, No. 7. Ecological Society of America, Washington, DC. http://esa.sdsc.edu/issues9.htm.

Hubbard, B., D. Faircloth, and A. Long. 1999. Recreation options for your forestland. Factsheet SS FOR 4. School of Forest Resources and Conservation, Florida Cooperative Extension Service, Institute of Food and Agricultural Sciences, University of Florida.

ICMA, International City/County Management Association. 2002. Getting to Smart Growth: 100 Policies for Implementation. 3 June 2002. http://www.smartgrowth.org/pdf/gettosg.pdf.

ICRAF, International Centre for Research in Agroforestry. 2000. Trees of Change: Corporate Report 2000. International Centre for Research in Agroforestry, Nairobi, Kenya.

IFCAE, Institute for Culture and Ecology. 2003. Southeastern States Regional Workshop: Harvester involvement in inventorying and monitoring of nontimber forest products. Atlanta, GA, Feb. 2003. www.ifcae.org/projects/ncssf1/southeastwksp/ index.html 
Israel, G.D. 1990. Characteristics of forest landowners in Northeast Florida. Extension Document PE-9. Institute of Food and Agricultural Sciences, University of Florida.

Israel, G.D. and D.L. Ingram. 1990. Characteristics of small farm operators in North Central Florida. Extension Document PE-10. Institute of Food and Agricultural Sciences, University of Florida.

Jackson, R.B., S.R. Carpenter, C.N. Dahm, D.M. McKnight, R.J. Naiman, S.L. Postel, and S.W. Running. 1997. Water in a Changing World. Issues in Ecology, No. 9. Ecological Society of America, Washington, DC. http://esa.sdsc.edu/issues9.htm.

Jacobson, S.K. 1990. Graduate education in conservation biology. Conserv. Biol. 4:431-440.

Johnson, G.V. and W.R. Raun. 1995. Nitrate leaching in continuous winter wheat: use of a soil-plant buffering concept to account for fertilizer nitrogen. J. Prod. Agric. 8:486-491.

Johnson R.H. and P.W. Bush. 2002. Summary of the hydrology of the Floridan Aquifer System in Florida and in Parts of Georgia, South Carolina, and Alabama. Professional Paper 1403-A. Center for Coastal Geology, U.S. Geological Survey, U.S. Department of the Interior. http://sofia.usgs.gov/publications/papers/pp1403a/ abstract.html.

Jones, E.T., R.J. McLain, and J. Weigand (eds.). 2002. Nontimber Forest Products in the United States. Univ. Press of Kansas, Lawrence, KS.

Jordan, C.F. 1998a. Alley Cropping. pp. 14.1-14.5 In P.G. Cannon (ed.) Exploring agroforestry opportunities in the South. Southern Agroforestry Conference sponsored by the Natural Resources Conservation Service, the US Forest Service, and Alabama A\&M University. Oct. 1998. Huntsville, AL.

Jordan, C.J. 1998b. Working with Nature: Resource Management for Sustainability. Overseas Publishers Assoc (OPA), Harwood Academic Publ., Amsterdam.
Jose, S., A. Gillespie, J. Siefert, and D. Biehle. 2000a. Defining competition vectors in a temperate alley cropping system in the midwestern USA: 2. Competition for water. Agrofor. Syst. 48:41-59.

Jose, S., A.R. Gillespie, J.R. Siefert, D.B. Mengel and P.E. Pope. 2000b. Defining competition vectors in a temperate alley cropping system in the midwestern USA: 3. Competition for nitrogen and litter decomposition dynamics. Agrofor. Syst. 48:61-77.

Josiah, S.J. (ed.). 1999. Farming the forest for specialty products. Proc. North American Conference on Enterprise Development through Agroforestry. The Center for Integrated Natural Resources and Agriculture Management (CINRAM) at the University of Minnesota, St. Paul, MN.

Josiah, S.J. 2001a. Edible Woody Landscapes for People and Wildlife. School of Natural Resources and Cooperative Extension, University of Nebraska, Lincoln, NE.

Josiah, S.J. 2001b. Marketing Specialty Forest Products. School of Natural Resources and Cooperative Extension, University of Nebraska, Lincoln, NE.

Josiah, S.J. 2001c. Productive Conservation: Growing Specialty Forest Products in Agroforestry Plantings. School of Natural Resources and Cooperative Extension, University of Nebraska, Lincoln, NE.

Katz, B.G. and J.K. Bohlke. 2000. Monthly variability and possible sources of nitrate in ground water beneath mixed agricultural land use, Suwannee and Lafayette Counties, Florida. Water-Resources Investigations Report 00-4219. U.S. Geological Survey/Florida Department of Environmental Protection. http://fl.water.usgs.gov/PDF_files/ wri00_4219_katz.pdf.

Kettler, J.S. (ed.). 1995. Proceedings of Southeastern Agroforestry Workshop. Sept. 1995, Athens GA. UGA Crop and Soil Science and Institute of Ecology along with USDA Natural Resources Conservation Service. 
Kidd, C.V. and D. Pimentel. 1990. Integrated

Resource Management: Agroforestry for Development. Academic Press, Harcourt Brace Jovanovich Pubs., in cooperation with the American Association for the Advancement of Science, Committee on Population, Resources, and the Environment, NY.

Kort, J. 1988. Benefits of windbreaks to field and forage crops. Agric. Ecosyst. Environ. 22/23:165-190.

Kuhn, G. and J. Nuss. 2000. Wastewater Management Using Hybrid Poplar. Agroforestry Notes AF Note -17. USDA National Agroforestry Center.

Kurtz, W.B. 2000. Economics and policy of agroforestry. pp. 321-360 In H.E. Garrett, W.J. Rietveld and R.F. Fisher (eds.) North American Agroforestry: An Integrated Science and Practice. American Society of Agronomy, Madison WI.

Kurtz, W.B., S.E. Thurman, M.J. Monson, and H.E. Garrett. 1991. The use of agroforestry to control erosion: Financial aspects. For. Chron. 67:254-257.

Lambin, E.F., B.L. Turner, H.J. Geist, S.B. Agbola, A. Angelsen, J.W. Bruce, O.T. Coomes, R. Dirzo, G. Fischer, and C. Folke. 2001. The causes of land-use and land-cover change: Moving beyond the myths. Global Environmental Change 11:261-269.

Lappé, F.M., J. Collins, and P. Rosset, with L. Esparza. 1998. World Hunger: 12 Myths. Grove Press/Earthscan.

Lassoie, J.P. and L.E. Buck. 2000. Development of agroforestry as an integrated land use management strategy. pp. 1-29 In H.E. Garrett, W.J. Rietveld, and R.F. Fisher (eds.) North American Agroforestry: An Integrated Science and Practice. American Society of Agronomy, Madison WI.

Lassoie, J.P., P. Huxley and L.E. Buck. 1994. Updating our ideas about agroforestry education and training. Agrofor. Syst. 28:5-19.

Leakey, R.R.B. 1996. Definition of agroforestry revisited. Agrofor. Today 8 (1):5-6.
Leakey, R.R.B. 1998. The use of biodiversity and implications for agroforestry. pp. 43-58 In D.E. Leihner, T.A. Mitschein, and P. Lang (eds.) A Third Millennium for Humanity? The Search for Paths of Sustainable Development. Frankfurt, Germany.

Leakey, R.R.B. and A.J. Simons. 1997. The domestication and commercialization of indigenous trees in agroforestry for the alleviation of poverty. Agrofor. Syst. 38:165-176.

Lee K.H. and S. Jose. 2001. Soil respiration under different land management practices in Northwestern Florida. p. 54 In Program Abstracts, Seventh Biennial Conference on Agroforestry in North America, August 13-15, 2001, Regina, Sask., Canada.

Lewis, C.E. and H.A. Pearson. 1987. Agroforestry using tame pastures under planted pines in the southeastern United States. pp. 195-212 In H.L. Gholz (ed.) Agroforestry: Realities, Possibilities and Potentials. Nijhoff Junk, Dordrecht, The Netherlands.

Lewis, C.E., G.W. Tanner, and W.S. Terry. 1985. Double vs. single-row pine plantations for wood and forage production. S. Journal Appl. For. 9:55-61.

Lewis, C.E., G.W. Burton, W.G. Monson, and W.C. McCormick. 1983. Integrations of pines, pastures and cattle in south Georgia, USA. Agrofor. Syst. 1:277-297.

Linnartz, N.E. and J.J. Johnson. (eds.) 1984. 33rd Annual Forestry Symposium, Louisiana State University Agricultural Center, Baton Rouge, LA.

Lohr, L. 1995. Economics of agroforestry. pp. 9-10 In J. Kettler (ed.). Proceedings of Southeastern Agroforestry Workshop. Sept. 1995, Athens GA. UGA Crop and Soil Science and Institute of Ecology along with USDA Natural Resources Conservation Service.

Long, A.J. and P.K.R. Nair. 1999. Trees outside forests: Agro-, community, and urban forestry. New Forests 17:145-174. 
Lowrance, R., R. Leonard, L. Asmussen, and R. Todd. 1985. Nutrient budgets for agricultural watersheds in the southeastern Coastal Plain. Ecology 66:287-296.

Lowrance, R., R.G. Williams, S.P. Inamdar, D.D. Bosch, and J.M. Sheridan. 2001. Evaluation of Coastal Plain conservation buffers using the riparian ecosystem management model. J. Amer. Water Resour. Assoc. 37:1445-1455.

Lowrance, R., L.S. Altier, J.D. Newbold, R.R. Schnabel, P.M. Groffman, J.M. Denver, D.L. Correll, J.W. Gilliam, J.L. Robinson, R.B. Brinsfield, K.W. Staver, W. Lucas, and A.H. Todd. 1997. Water quality functions of riparian forest buffers in the Chesapeake Bay Watershed. Environ. Manage. 21:687-712.

Malik, R.K., T.H. Green, G.F. Brown, and D. Mays. 2000. Use of cover crops in short rotation hardwood plantations to control erosion. Biomass and Bioenergy 18:479-487.

Marshall, M.G. and C.F. Bennett (eds.). 1998. Volume 6. Outputs of drinking water quality programs. National Extension Targeted Water Quality Program, 1992-1995. Texas A\&M University, State College, TX, cooperating with Cooperative State Research, Education, and Extension Service (CSREES), USDA.

Mater, C. 1994. Minnesota special forest products: A market study. Mater Engineering and Minn. Dep. Of Nat. Res., Corvallis, OR.

Matson, P.A., W.J. Parton, A.G. Power, and M.J. Swift. 1997. Agricultural intensification and ecosystem properties. Science 277:504-509.

Matta-Machado, R.P. and C.F. Jordan. 1995. Nutrient dynamics during the first three years of an alley cropping agroecosystem in southern USA. Agrofor. Systems 30:351-362.

McGowan, C.H., L. Carter, S. Pancholy, and B.R. Phills. 1999. Statewide Goat Program: Program Plan. Florida Agricultural and Mechanical University, College of Engineering Sciences, Technology and Agriculture, Tallahassee, FL.
McGraw, R.L, N.E. Navarrete-Tindall, and J.W. Van Sambeek. 2001. Effects of shade on growth and nodulation of six native legumes with potential for use in agroforestry. p. 50 In Program Abstracts, Seventh Biennial Conference on Agroforestry in North America. August 13-15, 2001, Regina, Sask., Canada.

McLeod, K.W., C. Sherrod Jr., and T.E. Porch. 1987. Response of longleaf pine plantations to litter removal. For. Ecol. Manage. 2:1-12.

Mercer, D.E. and R.P. Miller. 1997. Socioeconomic research in agroforestry: Progress, prospects and priorities. Agrofor. Syst. 38:177-193.

Merwin, M. 1997. The Status, Opportunities, and Needs for Agroforestry in the United States. Association for Temperate Agroforestry (AFTA), University of Missouri, Columbia, MO.

Miller, R.A. 1988. Native plants of commercial importance. OAK, Grants Pass, OR.

Montagnini, F. and P.K.R. Nair. 2004. Carbon sequestration: An under-exploited environmental benefit of agroforestry systems. Agrofor. Syst. (in press).

Morris, L.A., E.J. Jokela, and J.B. O'Conner. 1992. Silvicultural guidelines for pinestraw management in the southeastern United States. Georgia For. Res. Pap. 88. Georgia Forestry Commission, Macon, GA.

Morton, J.F. 1981. Atlas of medicinal plants of Middle America: Bahamas to Yucatan. CC Thomas Pub., Springfield, IL.

Mueller, J.P., J.M. Luginbuhl, and B.A. Bergmann. 2001. Establishment and early growth characteristics of six Paulownia genotypes for goat browse in Raleigh, NC, USA. Agrofor. Syst. 52:63-72.

Muller, E.U. and S.J. Scherr. 1990. Planning technical interventions in agroforestry projects. Agrofor. Syst. 12:23-44.

NAC, National Agroforestry Center. 1998. Working Trees for Wildlife. USDA National Agroforestry Center, Lincoln, NE. 
NAC, National Agroforestry Center. 2000a. Working Trees for Carbon: Windbreaks in the U.S. USDA National Agroforestry Center, Lincoln, NE. http://www.unl.edu/nac/brochures/wbcarbon/ wbcarbon.pdf.

NAC, National Agroforestry Center. 2000b. Working Trees for Carbon Cycle Balance. USDA National Agroforestry Center, Lincoln, NE. http://www.unl.edu/nac/brochures/wtcarbon/ wtcarbon.pdf.

Naiman, R.J., H. Decamps, and M. Pollock. 1993. The role of riparian corridors in maintaining regional biodiversity. Ecol. Applications 3:209-212.

Nair, P.K.R. 1993. An Introduction to Agroforestry. Kluwer Acad. Publ., Dordrecht, Netherlands.

Nair, P.K.R. 1994. Agroforestry. Encyclopedia of Agricultural Science 1:13-25, Academic Press, New York, NY.

Nair, P.K.R. and M.E. Bannister. 2001. Center for Subtropical Agroforestry: A new initiative for the southeastern USA. Annual Meeting Abstracts, Charlotte, NC, November 2001.CD-ROM. Amer. Soc. Agron, Madison, WI.

Nair, P.K.R. and V.D. Nair. 2003. Carbon storage in North American agroforestry systems. pp. 333-346 In J.M. Kimble, L.S. Heath, R.A. Birdsey and R. Lal (eds.) The Potential of U.S. Forest Soils to Sequester Carbon and Mitigate the Greenhouse Effect. CRC Press, Boca Raton, FL.

Nair, P.K.R., H.L. Gholz, and M.L. Duryea (eds.). 1990. Agroforestry education and training: present and future. Forestry Sciences 35. Kluwer Acad. Publ., Dordrecht, Netherlands.

Nambiar, E.K.S., R. Sands, and P.M. Dougherty. 1993. Competition for water and nutrients in forests. p. 10 In G.R.G.D.H. Gjerstad, R.J. Mitchell, S.B. Horsley, R.A. Campbell, and S.M. Zedaker, (eds.) Proceedings of the International Conference on Forest Vegetation Management. May 1992. Auburn University. Vol. 23. Canadian J. For. Res.
NARC\& DC, USDA National Association of RC\&D Councils. 2000. RC\&D Survey of Agroforestry Practices. Spring, 2000. Washington, DC.

NASS, National Agricultural Statistics Service. 2001. Derived from data at http://goveinfo.library.orst.edu/document/ag97/ agcont.html.

NCDC, National Climatic Data Center. 2002. Climate of 2001 - Annual Review. http://lwf.ncdc.noaa.gov/oa/climate/research/2001/ win/us_regional.html.

Newman, S.M. and A.M. Gordon. 1997. Temperate agroforestry: synthesis and future directions. pp. 251-266 In A.M. Gordon and S.M. Newman (eds.) Temperate Agroforestry Systems. CAB International, Wallingford, UK.

Ng H.Y.F., C.F. Drury, V.K. Serem, C.S. Tan, and J.D. Gaynor. 2000. Modeling and testing of the effect of tillage, cropping and water management practices on nitrate leaching in clay loam soil. Agric. Water Manage. 43:111-131.

Norton, R.L. 1988. Windbreaks: Benefits to orchard and vineyard crops. Agric. Ecos. Environ. 22/23:165-190.

Nowak, J. and A. Blount. 2002. Silvopasture More than Cattle Grazing in Pine Plantations. Forest Landowner 61 (2):10-13.

NRC, National Research Council, Board on Agriculture. 1998. Changing conditions of the forest. pp. 57-71 In Forested landscapes in perspective: prospects and opportunities for sustainable management of America's nonfederal forests. National Academy Press, Washington, DC.

NRCS, Natural Resource Conservation Service. 1997. Alley cropping. Conservation Practice Job Sheet No. 311. USDA Natural Resource Conservation Service, Washington, DC.

Onokpise, O., L. Carter, J. Beauduin, and A. Jakes. 2002. Agrosilvopastoral System Involving Meat Goats and Swine, Tallahassee, Florida. 
Available by Center for Subtropical Agroforestry. http://cstaf.ifas.ufl.edu.

Orfanedes, M., J. Crane, and C. Balerdi. 2001. Tropical and Subtropical Fruit Crops for the Home Landscape: Alternatives to Citrus. Part of a series of the Horticultural Sciences Department. Tropical Research and Education Center, University of Florida.

Orr, D. 1991. Biological diversity, agriculture, and the liberal arts. Conserv. Biol. 5:268-270.

Palada, M. 2002. Tree-crop Integration with High-value Horticultural Crops, St. Croix, Virgin Islands. http://cstaf.ifas.ufl.edu.

Pallardy, S., D. Gibbins, and J. Rhoads. 2002. Above and below-ground biomass production by two-year-old poplar clones on floodplain sites in the lower Midwest, U.S.A. pp. 34-39 In W. Schrodder and J. Kort (eds.) Proceedings of the Seventh Biennial Conference on Agroforestry in North America. August 13-15, 2001, Regina, Sask., Canada.

Parry, M. 2001. Climate change: Where should our research priorities be? Global Environmental Change 11:257-260.

Pearson, H.A. 1975. Exotic grass yields under southern pines. USDA Forest Service Southern For. Exper. Stat. Res. Note SO-201. New Orleans, LA.

Pearson, H.A. 1997. Silvopastures: Forest grazing and agroforestry in the southern Coastal Plain. pp. 25-42 In D. Henderson (ed.) Proc. Mid-South Conf. On Agroforestry Practices and Policies. West Memphis, AR. Aug 1991. Winrock International Inst. For Agric. Development. Morrilton, AR.

Pearson, H.A. and A. Martin Jr. 1991. Goats for vegetation management on the Ouachita National Forest. pp. 59-73 In G. Solaiman and W.A. Hill (eds.) 1991. Using goats to manage forest vegetation: A regional inquiry. Workshop Proceedings. Tuskegee University Agricultural Experiment Station, Tuskegee, AL.

Pearson, H.A., V.C. Baldwin, and J.P. Barnett. 1990. Cattle grazing and pine survival and growth in sub-terranean clover pasture. Agrofor. Syst. 10:161-168.

Prestemon, J. and R. Abt. 2002. Timber products supply and demand. Chapter 13, pp. 299-325 In D.N. Ware and J.G. Greis (eds.) Southern Forest Resource Assessment. USDA Forest Service GTR SRS-53.

Primault, B. 1979. Optimum climate for animals. pp. 182-189 In J. Seemannetal (ed.)

Agrometeorology. Springer-Verlag, Berlin, Germany.

Qiu, Z. and T. Prato. 1998. Economic evaluation of riparian buffers in an agricultural watershed. J. Am. Water Resources Assoc. 34:877-884.

Ramsey, C. and S. Jose. 2002. Management challenges of temperate alley cropping systems from southern USA. pp. 158-163 In W. Schrodder and J. Kort (eds.) Proceedings of the Seventh Biennial Conference on Agroforestry in North America., August 13-15, 2001, Regina, Sask., Canada.

Rathke, D.M. and M.J. Baughman. 1993. Can shiitake production be profitable? Shiitake News 10 (1):1-7,10,13.

Reid, W.R. 1991. Low input management systems for native pecans. pp. 140-158 In H.E. Garrett (ed.) Proc. Second Conference on Agroforestry in North America, August 1991, Springfield, MO.

Rhoades, C.C., T.M. Nissen, and J.S. Kettler. 1998. Soil nitrogen dynamics in alley cropping and no-till systems on Ultisols of the Georgia Piedmont, U.S.A. Agrofor. Syst. 39:31-44.

Rietveld, W.J. and S.W. Workman. 1998. Compendium of institutional agroforestry activities: A computer database of existing agroforestry research, teaching, extension and international activities in the USA. Available by USDA National Agroforestry Center, Lincoln, NE. http://www.unl.edu/nac/database/index.html.

Robinson, J. and T. Clason. 1997. From a pasture to a silvopasture system. Agroforestry Notes AF Note - 22. USDA National Agroforestry Center, Lincoln, NE. 
Robinson, J., S. Brantley, and T. Clason. 2001. Silvopasture - From research to field applications: Researchers, multi-discipline technology transfer specialists and landowners getting the job done. p. 311 In Proceedings of the Seventh Biennial Conference on Agroforestry in North America. August 13-15, 2001, Regina, Sask., Canada.

Robles-Diaz-de-Leon, L.F., and P. Kangas. 1999. Evaluation of potential gross income from non-timber products in a model riparian forest for the Chesapeake Bay watershed. Agrofor. Syst. 44:215-225.

Rockwood, D.L. 1996. Using fast-growing hardwoods in Florida. Florida Energy Extension Service. University of Florida Fact Sheet EES-328. $8 \mathrm{p}$.

Rockwood, D.L. 1997. Eucalyptus -- Pulpwood, Mulch or Energy Wood? Circular 1194. School of Forest Resources and Conservation, Florida Cooperative Extension Service, Institute of Food and Agricultural Sciences, University of Florida.

Rockwood, D.L., N.N. Pathak, and P.C. Satapathy. 1993. Woody biomass production systems for Florida. Biomass \& Bioenergy 5 (1):23-34.

Sabota, C. 1993. The effects of Shiitake mushroom strains and wood species on the yield of Shiitake mushrooms. pp. 45-58 In Proc. National Shiitake Mushroom Symposium. Huntsville AL.

Sampson, R.N. and D. Hair. 1990. Natural resources for the 21st Century. Island Press, Washington, DC.

Sanford, M.T. 1988. Beekeeping: Florida bee botany. Circular 686, Florida Cooperative Extension Service, Institute of Food and Agricultural Sciences, University of Florida. 5p.

Sanford, M.T. 2000. Florida's climate and its beekeeping. Factsheet ENY-134, Entomology and Nematology Department, Florida Cooperative Extension Service, Institute of Food and Agricultural Sciences, University of Florida. 8p.

Savory, A. 1988. Holistic resource management. Island Press, Washington, DC.
Schaefer, J.M. and M.T. Brown. 1992. Designing and protecting river corridors for wildlife. Rivers 3:14-26.

Schimel, D.S., J.I. House, K.A. Hibbard, P. Bousquet, P. Ciais, P. Peylin, B.H. Braswell, M.J. Apps, D. Baker, A. Bondeau, J. Canadell, G. Churkina, W. Cramer, A.S. Denning, C.B. Field, P. Friedlingstein, C. Goodale, M. Heimann, R.A. Houghton, J.M. Melillo, B. Moore, D. Murdiyarso, I. Noble, S.W. Pacala, I.C. Prentice, M.R. Raupach, P.J. Rayner, R.J. Scholes, W.L. Steffen, and C. Wirth. 2001. Recent patterns and mechanisms of carbon exchange by terrestrial ecosystems. Nature 414:169-172.

Schlosser, W.E. and K. Blatner. 1997. Special forest products: An east-side perspective. USDA For. Serv. Gen Tech. Rep. PNW-GRT-380.

Schultz, R.C, J.P. Colletti, and R.R. Faltonson. 1995. Agroforestry opportunities for the United States of America. Agrofor. Syst. 31 (2):117-132.

Schultz, R.C., J.P. Colletti, T.M. Isenhart, C.O. Marquez, W.W. Simpkins, and C.J. Ball. 2000. Riparian forest buffer practices. pp. 189-281 In H.E. Garrett, W.J. Rietveld, and R.F. Fisher (eds.). North American agroforestry: An integrated science and practice. American Society of Agronomy, Madison, WI.

Scoones, I. and J. Thompson. 1994. Knowledge, power and agriculture - towards a theoretical understanding. p. 16 In Beyond Farmer First. I. Scoones and J. Thompson (eds). Intermediate Technology Publications, London.

SCS, Soil Conservation Service. 1991. Forest management: A viable alternative on marginal croplands eligible for the Conservation Reserve Program. Soil Conservation Service. U.S. Govt. Printing Office, Washington, DC.

Shannon, D. and L. Isaac. 1998. Alley cropping research experience in Haiti. pp. 15.1-15.10 In P.G. Cannon (ed.). Exploring agroforestry opportunities in the South. Southern Agroforestry Conference sponsored by the Natural Resources Conservation Service, the US Forest Service, and Alabama A\&M University. Oct. 1998. Huntsville, AL. 
Shannon, D., K. Yoo, and K. Kabaluapa. 2002. Environmental benefits of agroforestry systems: Soil and water conservation. Available by Center for Subtropical Agroforestry, School of Forest Resources, University of Florida. http://cstaf.ifas.ufl.edu.

Shrestha, R. and J.R.R. Alavalapati. 2002. Valuing environmental benefits of agroforestry using attribute-based stated preference method. Presented at 2nd World Congress of Environmental and Resource Economists. Monterey, CA, June 24-27, 2002.

Sinclair, F. 1999. A general classification of agroforestry practice. Agrofor. Syst. 46:161-180.

Smith, J.R. 1953. Tree crops: A permanent agriculture. The Devin-Adair Co., New York.

Soemarwoto, O. 1987. Homegardens: A traditional agroforestry system with a promising future. pp. 157-170 In H.A. Steppler and P.K.R. Nair (eds.) Agroforestry: A decade of development. International Centre for Research in Agroforestry, Nairobi, Kenya.

Solaiman, G. and W.A. Hill. (eds.) 1991. Using goats to manage forest vegetation: A regional inquiry. Workshop Proceedings. Tuskegee University Agricultural Experiment Station, Tuskegee, AL.

Soule, M.J., A. Tegene, and K.D. Wiebe. 2000. Land Tenure and the Adoption of Conservation Practices. Amer. Agr. Econ. 82:993-1005.

SRS, US Forest Service, Southern Research Station. 2002. Silvicultural Investments, SRS/RWU-4802 New Orleans, LA. http://www.srs.fs.fed.us/4802/

Silvicultural\%20Investments.htm.

Stamets, P. 2000. Growing Gourmet and Medicinal Mushrooms. Third Edition. Ten Speed Press, Berkeley, CA.

Stamps, W.T., T.W. Woods, M.J. Linit, and H.E. Garrett. 2002. Arthropod diversity in alley cropped black walnut (Juglans nigra L.) stands in eastern Missouri, USA. Agrofor Syst. 56:167-175.
Stein, T.V. 1998. Ecotourism: A new land management opportunity for private landowners. Florida Forests 5:36-38.

Svedin, U. 1999. Urban and non-urban environmental policies as expressions of changed perceptions about ways of handling societal change. pp. 231-242 In Lindqvist, C. and Wallenius, L.L. (eds.) Globalization and Its Impact On Chinese and Swedish Society. Stockholm, Sweden.

SWCS, Soil and Water Conservation Society. 2002. Seeking Common Ground: How Conservation Measures Up in the Farm Security and Rural Investment Act of 2002. Available online, posted June 20, 2002. http://www.swcs.org.

Sykes, K.J., A.W. Perkey, and R.S. Palone. 1994. Crop tree management in riparian zones. USDA Forest Service, Northeastern Area, State and Private Forestry, Morgantown, WV. http://www.fsl.wvnet.edu/frm/wateshed/riparian.html.

Tanner, G. 2002. Wildlife benefits of silvopastoral systems. University of Florida, North Florida Research and Education Center. Marianna, FL.

Tanner, G.W, J.J. Mullahey, and D. Maehr. 1999. Saw-palmetto: An ecologically and economically important native palm. Wildlife Ecology and Conservation Circular WEC-109. Florida Cooperative Extension Service, Institute of Food and Agricultural Sciences, University of Florida. 3 p.

Teal, W.S. and L.E. Buck. 2002. Between wildcrafting and monocultures: Agroforestry options. pp. 199-222 In E.T. Jones, R.J. McLain, and J. Weigand (eds.) Nontimber Forest Products in the United States. University Press of Kansas, Lawrence, KS.

Teasley, R.J., J.C. Bergstrom, H.K. Cordell, S.J. Zarnoch, and P. Gentle. 1997. The use of private lands in the U.S. for outdoor recreation: Results of a nationwide survey. UGA Faculty Series 97-19. University of Georgia, Athens, GA. 102 p.

Thomas, M.G. and D.R. Schumann. 1993. Income opportunities in special forest products. 
Agric. Inf. Bull. 666. USDA Forest Service, Washington, DC.

Twilley, R.R., E.J. Barron, H.L. Gholz, M.A. Harwell, R.L. Miller, D.J. Reed, J.B. Rose, E.H. Siemann, R.G. Wetzel, and R.J. Zimmerman. 2001. Confronting climate change in the Gulf Coast Region: Prospects for sustaining our ecological heritage. Union of Concerned Scientists and Ecological Society of America. UCS Publications, Cambridge MA. http://www.ucsusa.org.

Tyndall, J. and J. Colletti. 2002. Shelterbelts, livestock odor mitigation, and sustainable agriculture: A research framework. pp. 206-219 In W. Schroeder and J. Kort (eds.) Proceedings of the Seventh Biennial Conference on Agroforestry in North America. August 13-15, 2001, Regina, Sask., Canada.

UCS, Union of Concerned Scientists. 2001. Global warming. http://www.ucsusa.org/index.html.

USDA-NRCS-RID. 1997. National Resources Inventory. Land use since 1850. USDA, Natural Resources Conservation Service. www.nrcs.usda.gov

USDA-SARE. 2003. What is Sustainable Agriculture? USDA, Sustainable Agriculture Research and Education program. http://www.sare.org/htdocs/docs/SANand SARE.html

USFS, USDA Forest Service. 2002. Forest Legacy Program. http://www.southernregion.fs.fed.us/spf/coop/legacy/ default.htm.

Verchot, L.V., E.C. Franklin, and J.W. Gilliam. 1997. Nitrogen cycling in Piedmont vegetated filter zones: II. Subsurface nitrate removal. J. Environ. Qual. 26:337-347.

Vitousek, P.M., H.A. Mooney, J. Lubchenco, and J.M. Melillo. 1997. Human domination of earth's ecosystems. Science 277:494-499.

Wade, T. and P.S. Tucker. 1996. Florida water policy issues.

http://www.dep.state.fl.us/water/waterpolicy/ pubs.htm.
Wallace, D., W. Geyer, and J. Dwyer. 2000. Waterbreaks: Managed trees for the floodplain. Agroforestry Notes AF Note - 19. USDA National Agroforestry Center, Lincoln, NE.

Ware, D.N. 2002. Land Use. Chapter 6, pp.153-173 In D.N. Ware and J.G. Greis (eds.) Southern Forest Resource Assessment. USDA Forest Service GTR SRS-53.

Ware, D.N and J.G. Greis. 2002. Southern Forest Resource Assessment. USDA Forest Service in cooperation with the Environmental Protection Agency, U.S. Fish and Wildlife Service, Tennessee Valley Authority, Southern Group of State Foresters, and Southern Association of Fish and Wildlife Agencies. September 2002 with summary report October 2002.

Weigand, J. 2002. The Caribbean Basin: Florida, Puerto Rico, and the U.S. Virgin Islands. pp. 75-80 In E.T. Jones, R.J. McLain, and J. Weigand (eds.) Nontimber Forest Products in the United States. University Press of Kansas, Lawrence, KS.

Wells, G. 2002. Biotechnical streambank protection: The use of plants to stabilize streambanks. Agroforestry Notes AF Note - 23. USDA National Agroforestry Center, Lincoln, NE.

Welsch, D.J. 1991. Riparian forest buffers: Function and design for protection and enhancement of water resources. USDA Forest Service, document \# NA-PR-07-91. Northeastern Area S\&P Forestry, Radnor, PA.

West, B. 2002. Water Quality in the South. Chapter 19, pp. 455-477 In D.N. Ware and J.G. Greis (eds.) Southern Forest Resource Assessment. USDA Forest Service GTR SRS-53.

Williams, P.A., A.M. Gordon, H.E. Garrett, and L. Buck. 1997. Agroforestry in North America and its role in farming systems. pp. 9-84 In A.M. Gordon and S.M. Newman (eds.) Temperate Agroforestry Systems. CAB International, Oxon, UK.

Williamson, J. and P. Lyrene. 1997. Florida's Commercial Blueberry Industry. Fact Sheet HSP 742, of the Horticultural Sciences Department. Florida 
Cooperative Extension Service, Institute of Food and Agricultural Sciences, University of Florida.

Workman, S.W., M.E. Bannister, and P.K.R.

Nair. 2002a. Agroforestry in the southeastern United States: Current practices and potential for development. pp. 81-93 In W. Schroeder and J. Kort (eds.) Proceedings of the Seventh Biennial Conference on Agroforestry in North America. August 13-15, Regina, Sask., Canada.

Workman, S.W., M.E. Bannister, and P.K.R. Nair. 2003. Agroforestry potential in the southeastern United States: perceptions of landowners and extension professionals. Agroforesty Systems 59:73.-83

Workman, S.W., A.J. Long, S. Mohan, and M.C. Monroe. 2002b. Agroforestry: options for landowners. Factsheet FOR 104, School of Forest Resources and Conservation. Florida Cooperative Extension Service, Institute of Food and Agricultural Sciences, University of Florida.

Wright, D.G., R.W. Mullen, W.E. Thomason, and W.R. Raun. 2001. Estimated land area increase of agricultural ecosystems to sequester excess atmospheric carbon dioxide. Commun. Soil Sci. Plant Analysis 32 (11-12):1803-1812.

Wright, L.L. and J.W. Ranney. 1991. Short rotation woody crops: Using agroforestry technology for energy in the United States. Report:

CONF-9109448-1. Department of Energy, Washington, DC/Oak Ridge, TN.

Wright, S. 2000. Where river flows through forest. National Wildlife Federation. National Wildlife Magazine 38 (4):38-44.

Zinkhan, F.C. and D.E. Mercer. 1997. An assessment of agroforestry systems in the southern USA. Agrofor. Syst. 35:303-321. 